PONTIFICIA UNIVERSIDADE CATÓLICA DO RIO DE JANEIRO COORDENAÇÃO CENTRAL DE EXTENSÃO

DEPARTAMENTO DE DIREITO

\title{
INDENIZAÇÃO PELO INTERESSE POSITIVO EM CASO DE RESOLUÇÃO DO CONTRATO
}

DEPARTAMENTO DE DIREITO

Professora Orientadora: Paula Greco Bandeira

BRUNO PINA METZNER

RIO DE JANEIRO

2019 


\section{INDENIZAÇÃO PELO INTERESSE POSITIVO EM CASO DE RESOLUÇÃO DO CONTRATO}

Trabalho de conclusão de curso apresentado como exigência da PósGraduação de Direito dos Contratos da PUC-Rio, como parte dos requisitos parciais para a obtenção do título de Especialista.

Rio de Janeiro, março de 2019

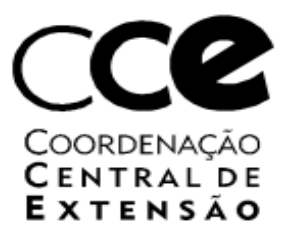


Aos meus professores, pela dedicação dispensada ao longo desse curso, e à minha família, pelo constante apoio, compreensão e carinho. 


\section{AGRADECIMENTOS}

Deixo registrados meus sinceros votos de gratidão ao corpo docente do curso do Direito dos Contratos da PUC-RIO, em especial à minha orientadora, pela paciência e dedicação, assim como aos meus colegas de curso pelas constantes trocas de ideias, que tornaram as aulas mais produtivas e agradáveis.

Especial agradecimento (sempre) à minha família, particularmente à minha querida prima Dani, por me ajudar a reunir o material necessário a esse trabalho, aos amigos, notadamente o Bruno Maggi, pela ajuda na revisão final de texto, e à minha companheira, Naty, pela paciência, compreensão e, sobretudo, pelo amor partilhado. 


\section{RESUMO}

O presente trabalho se propõe a analisar a possibilidade de cumulação da indenização pelo interesse positivo do contrato com o pedido de resolução do mesmo.

Para tanto, o autor examina individualmente, em capítulo distintos, a definição do que seria interesse contratual positivo e interesse contratual negativo, a divergência doutrinária acerca da cumulatividade do interesse positivo com a resolução contratual, bem como a posição firmada pelos Tribunais ao enfrentar diretamente a questão.

Ao final, tomando como base os elementos colhidos nos capítulos precedentes, o Autor faz uma análise crítica da questão e da forma com que tem sido enfrentada pelos Tribunais brasileiros, tanto de forma expressa, como implicitamente.

Pretende-se, com isso, contribuir para o aprofundamento da discussão e para a melhor compreensão dos institutos em exame, notadamente da cumulatividade objeto do estudo, cuja aplicação ainda se revela tormentosa do direito brasileiro, embora não encontre nenhum óbice legal.

Palavras-Chave: direito civil; indenização; interesse positivo; interesse negativo; resolução contratual; responsabilidade civil; descumprimento do contrato. 


\begin{abstract}
This paper aims to analyze the possibility of cumulating the indemnity for expectation interest of the contract with the request for termination.

The author examines, individually, the different legal institutes related to the matter, the divergence between the legal authorities regarding the cumulativeness of expectation interest with the request for termination, and, also, the position set by the Courts when dealing directly with the question.

At last, based on the elements gathered in the preceding chapters, the author critically analyzes the matter and the way in which it has been faced by the Brazilian Courts, either expressly or implicitly.

Therefore, by means of this paper, author intends to deepen the debate and the understanding of the institutes under examination, especially of the cumulativity object of the study, whose application is still tempestuous by Brazilian law, notwithstanding the lack of legal obstacles.
\end{abstract}

Keywords: civil law; indemnity; reliance interest; expectation interest; breach of contract; termination; civil liability. 


\section{LISTA DE ABREVIATURAS E SIGLAS}

Art. - Artigo

BGB - Bürgerliches Gesetzbuch (Código Civil Alemão)

CC - Código Civil

CC16 - Código Civil de 1916

CISG - Convenção das Nações Unidas sobre Contratos de Compra e Venda Internacional de Mercadorias - Uncitral

STJ - Superior Tribunal de Justiça

STJP - Supremo Tribunal de Justiça português

TJDFT - Tribunal de Justiça do Distrito Federal e Territórios

TJRS - Tribunal de Justiça do Estado do Rio Grande do Sul

TJRJ - Tribunal de Justiça do Estado do Rio de Janeiro

TJSP - Tribunal de Justiça do Estado de São Paulo

UERJ - Universidade do Estado do Rio de Janeiro

USP - Universidade do Estado de São Paulo 


\section{SUMÁRIO}

INTRODUÇÃ

1. CONCEITO DE INTERESSE POSITIVO E DE INTERESSE NEGATIVO .............14

2. A DIVERGÊNCIA DOUTRINÁRIA SOBRE A APLICAÇÃO DO INTERESSE POSITIVO EM CASO DE RESOLUÇÃO DO CONTRATO .............................22

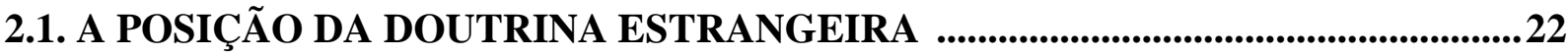

2.2. O debate doutrinário no Direito brasileiro ........................................................................27

2.2.1. CORRENTE CONTRÁRIA À INDENIZAÇÃO PELO INTERESSE POSITIVO EM CASO DE RESOLUÇÃO CONTRATUAL ..................................29

2.2.2. Corrente favorável à indenização pelo interesse positivo em caso de resolução

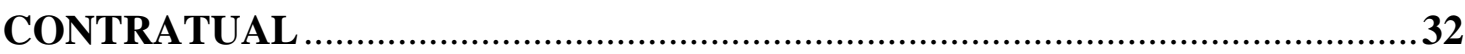

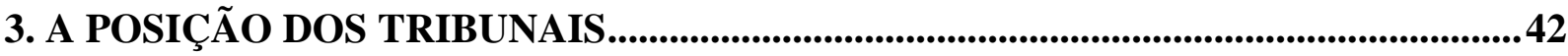

3.1. Introdução

3.2. Paradigmático precedente do Supremo Tribunal de Justiça português ........................42

3.3. Precedentes do Superior Tribunal de Justiça ...........................................................44

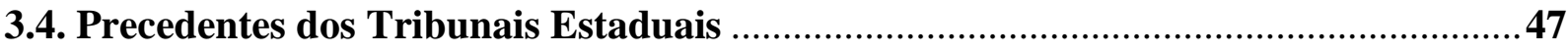

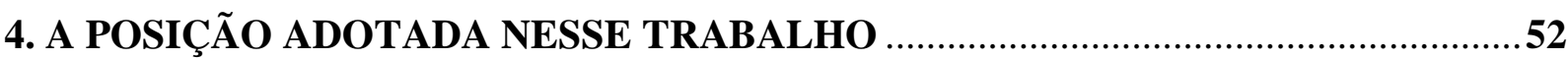

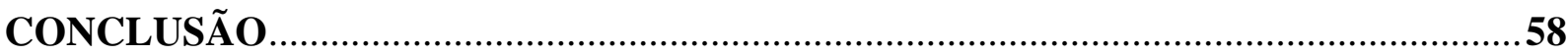

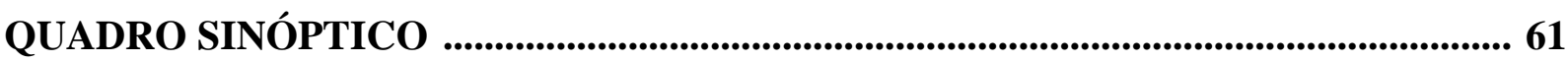

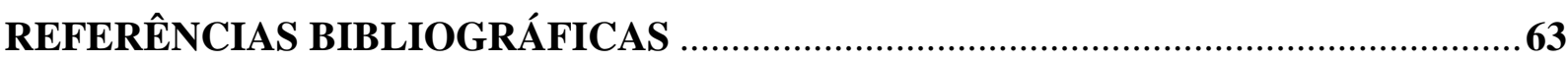




\section{INTRODUÇÃO}

A tutela da responsabilidade pré-negocial, que culminou na distinção entre interesse positivo e negativo, foi desenvolvida em meados do século XIX, na Alemanha, por Rudolf von Jhering, em sua obra denominada "Culpa in contrahendo ou indenização por contratos nulos ou não chegados à perfeição", na qual o autor reconheceu a existência de deveres de proteção e de boa-fé não só durante, mas, também, antes da formação do contrato. ${ }^{1}$

Em suma, o jurista tedesco defendia que o direito à reparação possuía um duplo direcionamento: reestabelecer o status quo ante à lesão (interesse negativo) ainda que se tratasse de contrato inválido ou não aperfeiçoados, bem como assegurar o status ad quem que seria alcançado caso a contratação fosse cumprida (interesse positivo). ${ }^{2}$

Com o passar do tempo, estudo acerca do interesse negativo e do interesse positivo evoluiu, ampliando a abrangência de tais institutos. A doutrina passou a debater, dentre outras questões, a possibilidade de haver interesse positivo e interesses negativo tanto na pré-contratual como na contratual, bem como se o interesse positivo seria conciliável com a resolução do contrato.

O presente trabalho se destina a examinar o justamente a última hipótese acima referida. Pretende-se debater se a indenização pelo interesse positivo pode ser pleiteada cumulativamente ao pedido de resolução contratual ou se somente é cabível caso o contratante pugne pelo cumprimento do pacto.

Não obstante a designada doutrina tradicional, representada por respeitáveis juristas brasileiros, opor-se à possibilidade de cumulação, pretende-se demonstrar que é plenamente viável obrigar a parte infratora a reestabelecer a situação patrimonial em que se encontraria a parte lesada caso o contrato tivesse sido adequadamente cumprido, mesmo que esta tenha exercido o seu direito de resolvê-lo.

\footnotetext{
${ }^{1}$ STEINER, Renata Carlos. Interesse positivo e Interesse negativo: a reparação de danos no direito privado brasileiro. 2016. Tese (Doutorado em Direito Civil) - Faculdade de Direito, Universidade de São Paulo, São Paulo, 2016, pp.1-2

${ }^{2}$ Ibid, p. 17
} 
Ver-se-á que a posição ora defendida, além de ter amparo na vanguarda do direito europeu, notadamente o português, o qual até pouco tempo também apresentava forte resistência, é igualmente respaldada por boa parte da doutrina nacional e, inclusive, pelo Superior Tribunal de Justiça.

Além disso, parece ser esta a posição que melhor se coaduna com a legítima expectativa contratual da parte lesada, bem como com a finalidade e a função econômica dos contratos, contribuindo para um ambiente comercial mais seguro e, por conseguinte, para o desenvolvimento econômico do país. Trata-se de posição que prestigia os efeitos do cumprimento - desfecho normal e esperado do pacto - e protege o interesse do credor adimplente, em detrimento daquele que culposamente deixou de cumprir o pacto havido, sem, entretanto, desequilibrar a relação.

Ver-se-á que o maior temor da corrente tradicional - a quebra do sinalagma e o risco de enriquecimento sem causa - é facilmente superado pela aplicação da teoria das diferenças. Por isso, dizemos que a corrente que defende a cumulatividade é a que melhor se enquadra nos dispositivos legais aplicáveis à questão: arts. 475, 402 e 944 do Código Civil.

Não obstante, cogita-se que pelo fato de os interesses positivos e negativos serem pouco debatidos no direito brasileiro em profundidade, verificou-se uma certa resistência nos julgados mais recentes das Cortes de justiça ordinárias em admitir a indenização pelo interesse contratual positivo nos casos em que há a resolução contratual.

Diante disso, para a melhor compreensão da questão, primeiramente será feita uma análise teórica dos institutos dos interesses positivo e negativo, apresentando-se o conceito de cada um (Capítulo 1). Em seguida exporemos as posições doutrinárias, nacional e estrangeira, e as divergências acerca da cumulatividade do interesse positivo com a resolução do contrato (Capítulo 2). Pretende-se, assim, facilitar a compreensão dos conceitos de interesse negativo e interesse positivo, pouco explorados pela doutrina clássica brasileira, bem como evidenciar os pontos controvertidos existentes quando a indenização abarca os interesses positivos em casos de resolução contratual. O terceiro capítulo será dedicado ao estudo jurisprudencial, mediante análise de julgados favoráveis e contrários à tese defendida nesse trabalho. Almeja-se, com isso, demonstrar a 
resistência dos Tribunais ordinários em prover, conjuntamente, pedidos de resolução contratual e de indenização pelo interesse positivo, quando a questão é posta no centro da discussão.

Por fim, mediante confronto entre as posições doutrinárias e por meio de uma análise crítica da jurisprudência, o capítulo quatro será reservado à exposição da orientação adotada neste trabalho. 


\section{CONCEITO DEINTERESSE POSITIVO E DE INTERESSE NEGATIVO}

Os conceitos de interesse positivo e negativo não estão expressos na legislação brasileira vigente e tampouco são usualmente explorados no cotidiano forense e acadêmico nacional.

Trata-se de expressões composta por dois vocábulos, criadas em outro contexto histórico, de modo que, para melhor compreendê-las, convém resgatar suas origens, bem como decompô-las, examinando seus termos de forma individual e contextualizada.

Tais expressões tem origem na doutrina de Rudolf von Jhering. Em sua obra "Culpa in contrahendo ou indenização por contratos nulos ou não chegados à perfeição", o jurista alemão as criou para diferenciar a responsabilidade por danos pré-contratuais e a responsabilidade decorrente de danos provocados durante a vigência de contratos válidos e eficazes. ${ }^{3}$

A partir do momento em que passou a reconhecer a existência de uma responsabilidade pré-contratual - ou seja, em que se admitiu a responsabilização antes mesmo de haver um contrato válido - o jurista alemão reputou necessário, também, definir um termo para delimitar os prejuízos indenizáveis nesse novo caso.

Isso porque, ainda que aplicável o regime da responsabilidade contratual à fase pré-contratual, entendia-se que os danos reparáveis causados no âmbito de contratos válidos não poderiam ser os mesmos daqueles oriundos de contratos inválidos. ${ }^{4}$ Em razão dessa dicotomia, verificada originalmente, foi preciso distinguir os interesses envolvidos em cada caso.

Assim, Jhering convencionou chamar de positiva a responsabilidade advinda do interesse em manter o contrato violado, portanto, já em vigor (válido),

\footnotetext{
${ }^{3}$ STEINER, Renata Carlos. Interesse positivo e Interesse negativo: a reparação de danos no direito privado brasileiro. 2016. Tese (Doutorado em Direito Civil) - Faculdade de Direito, Universidade de São Paulo, São Paulo, 2016, pp. 14-15

4 À época, Jhering entendia que o interesse positivo, por estar ligado e pressupor a existência de um contrato válido, não seria aplicável à culpa in contrahendo, prévia à celebração do contrato Afinal, se não havia contrato, não se poderia pugnar pelos danos relativos ao seu (des)cumprimento.
} 
e, de negativa, a responsabilidade oriunda do interesse na não conclusão do contrato, cujas tratativas foram rompidas, ou seja, a responsabilidade advinda da culpa in contrahendo.

Com efeito, o termo "positivo" se justifica porque se pretendia manter o contrato (ação positiva). Já o termo "negativo", porque a intenção era de não concluir o contrato que se negociava (ação negativa).

É o que se extrai do primoroso estudo dedicado ao tema, de autoria de Renata Carlos Steiner, em sua tese de doutoramento apresentada à Universidade de São Paulo:

"Sendo o contrato inválido, dele não se pode extrair um dever de prestação ou de cumprimento, o qual restaria extinto com a decretação de invalidade. Seria, portanto, contrário à decretação de invalidade que a indenização respectiva recolocasse o lesado na situação de cumprimento do contrato invalidamente formado. Essa recondução somente seria cabível na hipótese de descumprimento de contratos válidos.

Foi, em essência, a partir da dicotomia entre validade vs invalidade que se apresentou um duplo direcionamento dos danos: de um lado, poderia haver interesse na manutenção do contrato, ou seja, no cumprimento, o que pressupunha a existência e validade do pacto; por outro, poderia haver interesse na não conclusão do contrato, o qual se ligava à invalidade do contrato. Apenas por razões de síntese, o primeiro foi denominado interesse contratual positivo $e$, o segundo, interesse contratual negativo.

A proposição surge para diferenciar os direcionamentos possíveis da reparação do dano contratual, o qual não poderia mais ser entendido como dotado de um sentido unívoco. Outrossim, haveria um dano causado pelo descumprimento e outro, também contratual, causado pela culpa in contrahendo." 5

Já o vocábulo “interesse", no contexto do século XIX, vinculava-se à noção romana de id quod interest, que, atualmente, corresponde às perdas e danos ou ao dano indenizável. ${ }^{6}$

Assim, conjugando-se ambos os termos, chega-se à conclusão de que, na proposição original, a expressão "interesse positivo" servia para definir o dano indenizável decorrente da validade do contrato, enquanto que o "interesse negativo" representava o dano indenizável decorrente da sua invalidade. ${ }^{7}$

para quantificar-se o dano, por seu turno, adotou-se a designada "teoria das diferenças", consistente na diferença obtida a partir da comparação entre os dois

\footnotetext{
${ }^{5}$ Op. Cit., p. 17

${ }^{6}$ Ibid p. 20

${ }^{7}$ Ibid, p. 21
} 
estados da parte lesada: (i) aquele em que ela de fato se encontrava em razão do ato lesivo praticado pela parte contrária; e (ii) aquele em que ela se encontraria, hipoteticamente, não fosse a ocorrência do ato lesivo. A diferença entre (i) e (ii) compunha o dano e poderia ser feita tanto no âmbito pré-contratual (negativa), quanto no contratual (positiva).

Com efeito, no âmbito do interesse negativo, em sua proposição original, o dano corresponderia àquilo que a parte lesada perdeu na fase pré-contratual e que não teria perdido, não fossem as negociações havidas com a parte infratora, ou seja, se o contrato não tivesse sido cogitado (situação a quo).

Já sob a perspectiva do interesse positivo, o dano corresponderia àquilo que o contratante auferiria se o contrato fosse adequadamente cumprido, ou seja, aquilo que ele deixou de auferir por conta do rompimento (situação ad quem).

Acompanhando a evolução do direito, os conceitos originalmente concebidos por Jhering foram aprimorados ao longo do tempo. Superando antigas limitações, os interesses positivo e negativo se desvincularam da proposição original de Jhering, que, por exemplo, delimitava o interesse negativo à fase précontratual. $^{8}$

Foram agregados novos elementos ao estudo, como a tutela da confiança, a partir dos quais o interesse negativo deixou de se vincular exclusivamente à culpa in contrahendo, passando a ter a finalidade também de recomposição da confiança lesada..$^{9}$

Com isso, estendeu-se a aplicação do interesse negativo também aos contratos já formados, válidos e eficazes, enquanto que alguns autores também passaram a admitir a existência de interesse positivo já na fase pré-contratual ${ }^{10}$.

\footnotetext{
${ }^{8}$ A evolução da interpretação e aplicação do interesse positivo e negativo é detalhadamente feita por Renata Steiner. Op. Cit., p 58-96

${ }^{9}$ Segundo Paulo Mota Pinto essa associação entre interesse negativo e proteção da confiança foi desenvolvida por Windscheid (MOTA PINTO, Paulo. Interesse contratual negativo e interesse contratual positivo. Coimbra: Ed. Coimbra, 2008, Vol. I;, p. 183)

${ }^{10}$ A aplicação do interesse positivo na fase pré-contratual, porém, ainda é bastante controvertida. Parte considerável da doutrina não admite a existência de interesse positivo na fase pré-contratual, em suma, por entender não ser possível conceder à parte os efeitos de algo que ainda sequer se formou. A título exemplificativo: J. M. de Azevedo Marques, "Ato ilícito. Promessa de locação não cumprida, Indenização. Lucros cessantes e quais os devidos”, RT 119/520-523, São Paulo: Ed. RT, p. 521 e Regis Fitchtner Pereira, "A responsabilidade civil pré-contratual, cit. P. 385 (In Gisela Guedes, ob. cit., p. 128, nota de rodapé 58. Em sentido contrário, CORDEIRO. António
} 
Mantida a essência conceitual original e a metodologia comparativa da teoria das diferenças, chegou-se, hodiernamente, à definição mais ampla de "interesse", como sendo a situação em que a parte prejudicada se encontraria sem a ocorrência do evento lesivo, independentemente do elo de ligação com a parte contrária (contratual ou pré-contratual).

Tal situação em que a parte deveria estar caso o ato lesivo não tivesse ocorrido pode ser verificada a partir da adição de algum elemento (p. ex. o cumprimento do contrato e consequente lucro que teria sido auferido), configurando, assim, o interesse positivo, ou pela abstração de algum evento ( $\mathrm{p}$. ex. inexistência das tratativas e, consequentemente, as vantagens que teriam sido obtidas em um contrato alternativo com terceiros que deixou de ser celebrado), caracterizando o interesse negativo. ${ }^{11}$

Por isso é que, Renata Steiner define "interesse positivo" como "a situação hipotética patrimonial na qual o lesado estaria se o contrato houvesse sido integral e adequadamente cumprido", de modo que a indenização, nesse caso, seguindo as lições de Paulo Mota Pinto, busca recolocar o lesado em um estado "ad quem", mediante a adição de um elemento que deveria ter ocorrido e não ocorreu (o cumprimento do contrato). ${ }^{12}$

Ou, de forma mais sucinta, nas palavras de Nelson Rosenvald e Cristiano Chaves, "o interesse positivo é o do cumprimento, pois corresponde ao acréscimo patrimonial que o credor teria se o contrato fosse objeto de adimplemento". ${ }^{13}$

Tal acréscimo patrimonial, consoante lição de Paulo Mota Pinto, corresponde a "uma diferença entre os valores da prestação e da contraprestação, que, tendo em conta a forma de avaliação da prestação em espécie, tanto pode ser uma diferença, para o dano do comprador: a) entre o preço do contrato e o preço da revenda; b) entre o preço do contrato e o preço numa compra de substituição; ou para o dano do vendedor: c) entre o preço do contrato e os custos do vendedor

Manuel da Rocha e Menezes. Da boa-fé no direito civil, $2^{\mathrm{a}}$ reimpressão. Coimbra: Almedina, 2001, p. 585 apud Renata Steiner, ob. cit., p. 92 e 119

${ }^{11}$ MOTA PINTO, Paulo. Vol. 1. Op. Cit., p. 842

12 Op. Cit., p. 45

${ }^{13}$ Curso de direito civil: contratos - teoria geral e contratos em espécie. 5 ed. rev. e atual. Salvador: Ed. Atlas, 2015, p. 551 
(designadamente o preço de abastecimento deste) ou d) entre o preço do contrato e o de uma venda de substituição ou cobertura". ${ }^{14}$

Poder-se-ia exemplificar a hipótese mencionada na alínea "a", acima, em que o lesado é o contratante, por meio da valorização da coisa objeto da contratação. Em termos concretos, seria a diferença de valor entre o preço do contrato não cumprido e o valor da coisa para o credor, como resultante do preço que obteria com a revenda dela a um terceiro. Verifica-se, também, na hipótese de o promissário comprador deixar de transferir o imóvel prometido porque o mesmo valorizou, retendo o bem e, consequentemente, a valorização imobiliária do mesmo, que, por força do contrato descumprido, seria auferida pelo promitente comprador.

No caso da alínea "b", por seu turno, tem-se o caso do comprador de um bem que não é entregue a tempo e que para poder substitui-lo por outro de igual qualidade tem que pagar um valor maior do que o preço originalmente contratado com o vendedor inadimplente (devido, por exemplo, à valorização de mercado de tal bem desde a data de celebração da compra inadimplida). Nessa circunstância, o interesse positivo corresponde a indenização pelo valor pago a mais na compra em substituição do bem não entregue a tempo.

Já a hipótese comentada pelo doutrinador lusitano na alínea "d”, em que a parte lesada é a contratada, pode ser verificada quando o comprador encomenda a produção de um bem perecível, pagando um sinal, mas, não conclui o pagamento do preço e desiste da compra, fazendo com o que o vendedor, para não perder a safra (mitigando seu prejuízo), tenha de vendê-la à outrem por um preço menor do que o acordado com o primeiro comprador. $\mathrm{O}$ dano positivo, aqui, consiste na diferença entre o preço do primeiro contrato (inadimplido) e o celebrado em substituição.

Existem, ainda, outras situações, destacadas por Araken de Assis ${ }^{15}$, que talvez não se encaixem em nenhuma das hipóteses abstratas conjecturadas pelo

\footnotetext{
${ }^{14}$ ob. cit., vol. II., p. 1657

${ }^{15}$ Diz o Autor que, no âmbito do interesse positivo, deve-se verificar "a vantagem que a prestação pontual traria para o parceiro. Se a prestação inadimplida for pecuniária, as perdas e danos correspondem aos juros de mercado (...); se for entrega da coisa, a privação pelo seu uso (aluguel) e da sua disponibilidade desde a época convencionada para o cumprimento." (Araken de Assis. Dano positivo e negativo na dissolução do contrato. Revista do Advogado, n 44/20-23.
} 
civilista português, como, por exemplo, a compensação por aquilo que a parte lesada obteria com o uso da coisa contratada, caso não tivesse sido privada dela.

Nesse contexto se enquadram os juros de mercado pela privação de determinada quantia pecuniária ou, então, o valor de aluguel pela privação do uso de outro bem qualquer. Em ambos os casos, a indenização seria paga em razão da indisponibilidade dos bens contratados por culpa da outra parte.

É o que se verifica com certa regularidade no cotidiano forense quando se disputa o direito do promissário comprador de receber alugueis que seriam pagos a ele pelo uso do imóvel comprado durante o período em que a construtora atrasou a entrega das chaves do mesmo.

Já o "interesse negativo", segundo doutrina contemporânea de Nelson Rosenvald e Cristiano Chaves, com escólio de Karl Larenz, corresponde ao “"dano à confiança', pois o credor foi lesado em sua confiança na celebração do contrato, realizando despesas e abrindo mão de outras oportunidades negociais" de modo que "[e]ssa indenização tem o condão de colocá-lo na situação em que estaria se não houvesse confiado na eficácia do contrato". ${ }^{16}$

A indenização, nesse caso, dirige-se apenas a compensar o investimento de confiança e abrange, assim como no interesse positivo, tanto os danos emergentes, quanto os lucros cessantes. Visa, porém, tão somente à defesa de um status quo, e não a realização de um status ad quem. ${ }^{17}$

Assim, conforme exemplifica Paulo Jorge Scartezzini Guimarães ${ }^{18}$, devese ressarcir o credor dos gastos realizados para a elaboração do negócio, como as despesas com advogados, despachantes, o eventual pagamento de tributos, despesas com o transporte da mercadoria, dentre outras. Inclui-se aqui o que a parte lesada eventualmente deixou de ganhar ao não ter efetuado, à época, outro negócio, ou seja, à "frustração de um lucro provável"19.

São Paulo, out/1994, pag. 21 apud GUEDES, Gisela Sampaio da Cruz. Lucros cessantes: do bom senso ao postulado normativo da razoabilidade, São Paulo: RT, 2011, p. 127

${ }^{16}$ Op. Cit., p. 551

${ }^{17}$ MOTA PINTO, Paulo. Op. Cit., p. 32

${ }^{18}$ In Responsabilidade civil e interesse contratual positivo e negativo (em caso de descumprimento contratual). In: Revista de Direito Privado. Vol. 63/2015, pp. 33-58. Jun/Set 2015. São Paulo, RT

${ }^{19}$ Antonio Chaves sustenta, ainda versando sobre o lucro cessante, que não pode "a liquidação do interesse negativo incidir sobre a parte em que exceder o positivo" para não ficar em situação melhor do que se encontraria com o cumprimento do contrato, ao que é contraditado por Gisela 
Verifica-se, portanto, que o interesse negativo pode abranger o que a legislação brasileira define como danos emergentes (gastos efetivos que não teriam sido despendidos se o contrato não existisse), assim como os lucros cessantes (lucro que a parte prejudicada auferiria com outros negócios que deixou de celebrar, ou seja, negócios de que abriu mão, em função do contrato rompido). ${ }^{20}$

É caso do contratante que deixa de contratar com A (um terceiro) para contratar com B, que, entretanto, não honra com as suas obrigações previstas no pacto celebrado. Tendo sido perdida a chance de contratar com A, o lucro que o contratante deixou de ganhar com aquele negócio integra o seu interesse negativo (lucros cessantes), juntamente com as despesas que ele incorreu para celebrar o contrato inadimplido por B (danos emergentes).

Em termos concretos, como bem observado por Judith Martins-Costa, têmse "num caso de campanha publicitária, os gastos com gravações, contratação de atores, honorários de artistas, projetos etc., também o aluguel de armazéns, de navios, (...) perdas sofridas por ter descuidado de providenciar acomodação em outro lugar das mercadorias necessárias, ou por ter recusado outros negócios ('perde d' une chance')". ${ }^{21}$

Também Antônio Chaves, citado por Gisela Guedes, traz alguns outros exemplos concretos que corresponderiam aos lucros cessantes no interesse negativo:

"O motorista de praça, retido por engano, o hoteleiro a quem fizeram erroneamente reservar quartos, poderiam não ter sofrido qualquer perda positiva. Mas se ambos, em consequência desse fato, rejeitaram outra ocasião,

Guedes com base no argumento de que esse "[n]ão é o caso do Brasil, onde não existe nenhuma limitação expressa". (Antonio Chaves, responsabilidade pré-contratual, 2.ed. São Paulo: Lejus, 1997, p. 208 apud Gisela Guedes, Lucros cessantes: do bom senso ao postulado normativo da razoabilidade, São Paulo: RT, 2011, p. 145-147)

20 "Ainda é fundamental dizer que o fato de estarmos diante de um interesse contratual negativo não impede um eventual pedido de lucros cessantes por parte do contratante prejudicado quando ele comprovar que tinha a alternativa, à época, de ter firmado outro contrato e que este lhe traria um determinado benefício" (Op. Cit.) No mesmo sentido, Gisela Guedes afirma que "o lucro cessante aqui não é o que o lesado razoavelmente deixou de ganhar com aquele negócio em particular, que fora descumprido, mas, sim, o que ele deixou de auferir por ter celebrado tal contrato, isto é, o que ele ganharia se tivesse, por exemplo, dado continuidade a outro negócio já em curso, ou, então, com o próprio investimento financeiro do capital." (Op. Cit., p. 145)

21 MARTINS-COSTA, Judith. Um aspecto da obrigação de indenizar: notas para uma sistematização dos deveres pré-negociais de proteção no direito civil brasileiro. In: Doutrinas Essenciais do Direito Civil. Vol. 4, pp. 693-746. Out/2010. 
que se lhes oferecia, de ver utilizado seu veículo ou seus quartos, a situação para eles, equivale a uma perda em dinheiro sonante." 22

Para melhor compreender a diferença entre a indenização lastreada em interesse negativos daquela lastreada em interesse positivos, confira-se o didático exemplo de Jorge Leite Areias Ribeiro de Faria ao enfrentar exatamente a controvérsia objeto desse trabalho:

\begin{abstract}
"Suponhamos que A, proprietário de um cavalo, que vale 600, o troca pelo automóvel de B, que vale 500. A venderia o automóvel a $C$ por 800 e, se não tivesse celebrado o contrato, teria tido a oportunidade de vender o cavalo a $D$ por 700. Entretanto, antes da entrega do carro, B tem um acidente e o carro fica totalmente destruído. B teve culpa no acidente. Atente-se agora na diferença de resultados práticos, consoante se trilha uma ou outra via. Se o credor optasse pelo direito à indenização [interesse positivo], receberia 800, mas entregaria o cavalo, de valor igual a 600. Se ele optasse pela resolução, não faria eventualmente a entrega do cavalo (assim, se ainda não tivesse realizado a contraprestação) e receberia 100 (o lucro que deixou de obter pela vinculação ao contrato resolvido) [interesse negativo]."23
\end{abstract}

Sem adentrar, por enquanto, no mérito da controvérsia relativa à cumulatividade de resolução com o interesse positivo, extrai-se do caso acima que, o credor (A) poderia receber do devedor (B): (i) os lucros cessantes pelo interesse negativo, no ordem de 100 (= 700 - 600), relativos ao contrato de venda do cavalo não celebrado com $\mathrm{D}$, ou, então, (ii) 200, correspondente à diferença entre o valor que C pagaria pelo automóvel (800) e o valor do cavalo (600), sendo este, portanto, os lucros cessantes relativos ao interesse positivo.

Verifica-se, portanto, que os conceitos de interesse negativo e de interesse positivo sofreram algumas alterações e tiveram a sua incidência ampliada desde que inicialmente propostos por Jhering. Eles mantêm, porém, a sua essência, consistente no restabelecimento, respectivamente, de um status quo ou de um status ad quem no quais a parte se encontraria não fosse o ato lesivo.

Por fim, verifica-se que ambos os interesses acima mencionados podem abranger tanto os danos emergentes, quanto os lucros cessantes suportados pela parte lesada e que, em termos práticos, a adoção de um ou de outro interesse repercute concretamente na análise e definição do dano indenizável, caso a caso.

\footnotetext{
${ }^{22}$ Antonio Chaves, responsabilidade pré-contratual, 2.ed. São Paulo: Lejus, 1997, p. 208-209 apud Gisela Guedes, Op. Cit., p. 146.

${ }^{23}$ FARIA. Jorge Leite Areias Ribeiro de. Direito das obrigações, vol.2. Coimbra: Almedina, 1990; pp. $428-429$
} 


\section{A DIVERGÊNCIA DOUTRINÁRIA SOBRE A APLICAÇÃO DO INTERESSE POSITIVO EM CASO DE RESOLUÇÃO DO CONTRATO}

\subsection{Posição da doutrina estrangeira}

Com exceção do direito lusitano, que sofreu forte influência da relativamente recente obra de Paulo Mota Pinto, pode-se dizer que a discussão em torno da controvérsia objeto desse trabalho já se encontra pacificada há mais tempo pela doutrina e jurisprudência europeia.

No âmbito do direito italiano, francês e alemão, este último após a reforma no BGB de 2002, parte majoritária da doutrina e dos tribunais reconhece o direito à indenização pelo interesse contratual positivo em caso de resolução do pacto, não havendo grande controvérsia, notadamente por conta da clareza da legislação lá vigente.

Sustenta-se, em suma, que a resolução não é apenas um meio de pôr fim ao contrato, mas, também, um dos remédios para tutelar os interesses do credor em caso de inadimplemento da obrigação, razão pela qual o seu exercício não pode ser interpretado de forma a prejudicar o direito indenizatório do credor. ${ }^{24}$

O italiano Pietro Trimarchi, lembrado por Paulo Jorge Scartezzini ${ }^{25}$, faz, ainda, uma interessante análise sob a perspectiva da função econômica do contrato. Segundo ele, a responsabilidade contratual tem a função de criar uma atmosfera de confiança que é pressuposto necessário para a realização de um contrato.

Para que isso ocorra e, consequentemente, haja estímulo à contratação, sob um prisma "econômico e social de remuneração pela iniciativa", é preciso que a responsabilidade contratual, não sirva apenas de incentivo ao devedor para que cumpra com a sua obrigação, mas, sobretudo, que proteja os interesses do credor em caso de inadimplemento, assegurando a ele o recebimento do equivalente pelo

\footnotetext{
${ }^{24}$ PINTO, Paulo Mota. Interesse contratual negativo e interesse contratual positivo. Coimbra: Coimbra Ed., 2008. vol. 2, p. 1604-1630

${ }^{25}$ TRIMARCHI, Pietro. Il contratto: inadempimento e rimedi. Milano: Giuffrè, 2010, p. 98 apud Guimarães, Paulo Jorge Scartezzini, Op. Cit.
} 
contrato descumprido; ou seja, assegurando a função econômica do contrato, que é o adimplemento.

No direito português, por seu turno, a questão é um pouco mais conturbada, sobretudo porque a lei em vigor equiparou os efeitos da resolução contratual aos da nulidade ${ }^{26}$, dando azo ao entendimento de que, ao resolver o contrato, a parte prejudicada colocaria fim ao mesmo, extirpando todos os seus efeitos retroativamente (ex tunc); ou seja, a resolução implicaria no desaparecimento do contrato. ${ }^{27}$

Assim, por uma questão de lógica, a parte lesada que o resolvesse, não poderia, em seguida, perseguir indenização por aquilo que auferiria se o contrato tivesse sido adequadamente cumprido (interesse positivo). Afinal, o contrato desapareceu. Restar-lhe-ia, então, o direito de reaver as prestações entregues sem a respectiva contraprestação e o de buscar reparação, seja pelas despesas que incorreu, seja pelas outras oportunidades de negócio que não teria perdido não fosse o contrato descumprido (ou seja, os danos emergentes e lucros cessantes circunscritos ao interesse negativo). ${ }^{28}$

Afirma-se, ainda, que admitir a indenização por aquilo que o credor auferiria se o contrato fosse adequadamente cumprido, ao mesmo passo em que se resolve o mesmo, implica em colocar o credor em uma posição melhor do que aquela em que ele estaria com o cumprimento. Afinal, com a resolução, aniquilarse-ia os efeitos do contrato, restituindo o credor ao seu estado original ao mesmo

\footnotetext{
${ }^{26}$ Segundo Paulo Jorge Scartezzini Guimarães, "prevê o art. 562. ${ }^{\circ}$ do CC luso que: 'Quem estiver obrigado a reparar um dano deve reconstituir a situação que existia, se não se tivesse verificado o evento que obriga a reparação'. Claramente percebe-se a distinção deste dispositivo com o nosso art. 475 do CC. Também não se pode esquecer que o legislador português equiparou os efeitos da resolução aos da nulidade (absoluta ou relativa), conforme consta do art. $433 .^{\circ}$ do seu CC, novamente, bem diferente do que fez o legislador brasileiro, já que a redação do nosso art. 182 é diversa da redação do art. 475, ambos do CC." (Op. Cit.)

${ }^{27}$ Em sede doutrinária, por todos, vide lição de Inocêncio Galvão Telles "A resolução do contrato bilateral, que é equiparada, quanto aos seus efeitos, à declaração de nulidade e à anulação do negócio jurídico (art. $433^{\circ}$ ), tem, como estas (art. $289^{\circ}, n^{\circ} 1$ ), valor retroativo, salvo se a retroatividade contrariar a vontade das partes (art. $434^{\circ}, n^{\circ} 1$ ). Retroage à data do contrato, produzindo efeito 'ex tunc'. O contrato desaparece no passado, tendo-se por não celebrado. As partes ficam desligadas dos seus compromissos como se nunca os tivessem contraído. Nenhuma delas pode ser compelida a executar esses compromissos; e, se o autor da resolução já satisfez o seu, tem direito a reaver por inteiro o que prestou (art. 801,$\left.n^{\circ} 2\right)$ ). (Direito das obrigaçôes, $7^{\mathrm{a}}$ ed., Coimbra; Ed. Coimbra, 2010, p. 462 apud SZTAJNBOK, Felipe. A indenização pelo interesse positivo como forma de tutela do interesse do credor nas hipóteses de inadimplemento culposo da obrigação. Civilistica.com. Rio de Janeiro, a. 3, n. 2, jul-dez./2014.

${ }^{28}$ ANTUNES VARELA, João de Matos. Das Obrigações em Geral, Volume II. 7. ${ }^{a}$ Edição, Coimbra: Ed. Almedina, 1997, pp. 109-112.
} 
tempo em que se reconheceria a este o direito de auferir os lucros que obteria com o contrato resolvido.

Com efeito, segundo a linha clássica portuguesa, ante a supra referida particularidade da legislação lá em vigor, o credor teria duas alternativas: (a) postular o cumprimento da obrigação, mantendo o contrato e, consequentemente, o direito de ser colocado na mesma situação em que estaria se o contrato tivesse sido cumprido voluntariamente e no modo/tempo/lugar devido (interesse contratual positivo) $\underline{\mathrm{OU}}$ (b) resolver o contrato e pleitear indenização para ressarcir a importância necessária para recolocá-lo na situação que estaria se o contrato não tivesse existido (interesse contratual negativo).

O posicionamento acima predominou por décadas em solo lusitano até ser veementemente enfrentado por Paulo Mota Pinto ${ }^{29}$, seguido por Menezes Cordeiro $^{30}$.

Em resposta à posição tradicional, os referidos autores sustentaram, em apertadíssima síntese, que, tal qual já reconhecido pela doutrina alemã, francesa e italiana, a resolução do contrato constitui um remédio em favor do credor para pôr fim à situação de inadimplemento contratual.

A resolução apenas põe termo e libera as partes dos deveres de prestações principais, não implicando em renúncia ao direito à reparação pelos prejuízos causados pela parte inadimplente, inclusive, pelo interesse positivo. Para eles, o vínculo obrigacional é uma realidade complexa que, além da obrigação principal, conta com deveres secundários e acessórios, inclusive o de indenizar, os quais não são destruídos pela resolução.

\footnotetext{
29 “'A resolução, como 'remédio' sinalagmático para o inadimplemento pelo vendedor, não deve pôr em causa outras consequências do não cumprimento não consumidas por aquele, contrariando-as, nem atribuir uma posição ao resolvente que já aparece sem qualquer relação com o fundamento (como uma posição melhor do que aquela em que o lesado estaria com o cumprimento). A contenção da retroactividade da resolução por não cumprimento é, pois justificada porque um efeito retroactivo ilimitado iria contrariar o fundamento e própria finalidade da resolução (que é reagir a um inadimplemento, afastando as suas consequências sobre o sinalagma contratual)". E acrescenta que "Se o argumento da retroactividade nunca poderia, pois, ser levado às últimas consequências, sob pena de contrariar o próprio fundamento da resolução (...) a verdade é que tal argumentação passa também ao lado da questão, decisiva, do fundamento para a atribuição de uma indemnização ao credor, e a sua relação com a medida desta." (ob. cit., vol. II, pág. 1644).

${ }^{30}$ António Manuel da Rocha e Menezes Cordeiro, Tratado de direito civil português, $2^{\circ}$ Vol: Direito das obrigações, Tomo IV. Coimbra: Almedina, 2010, pp. 159-163
} 
Com efeito, havendo dano, deve haver a respectiva reparação integral, sendo a resolução apenas uma forma de liberar os contratantes das obrigações principais às quais estão atrelados por força do contrato, enquanto ele viger.

No que tange à equiparação dos efeitos da resolução aos da nulidade do contrato, contra argumentam que se trata de leitura sobremaneira formal e que o efeito retroativo ilimitado é contraditório, pois retira do mundo jurídico o próprio descumprimento contratual que, em primeiro lugar, deu causa à resolução. $\mathrm{Ou}$ seja, a resolução se torna prejudicial ao próprio credor, pois os seus efeitos desfazem o contrato e também o ato ilícito (descumprimento) da parte infratora que deu ensejo à resolução, eximindo-a do dever de indenizar. ${ }^{31}$

Confira-se enxerto da obra de Menezes Cordeiro que resume com maestria tudo o que aqui exposto:

"Todavia, perante o moderno Direito das obrigações, não é possível vir afirmar que a resolução destrói retroativamente o contrato, suprimindo todas as obrigações dele derivadas. $O$ vínculo obrigacional é uma realidade complexa. A resolução apenas visa suprimir o dever de prestar principal do contraente fiel, perante o incumprimento definitivo do dever de prestar principal a cargo do contraente faltoso. Seria, na verdade, sumamente injusto que, perante o incumprimento da outra parte, o contratante fiel ainda devesse efectuar a sua prestação. Quer dizer que a resolução apenas põe termo aos deveres de prestação principais. Todos os demais deveres envolvidos, secundários e acessórios se mantêm.

(...)

A ideia de que, havendo resolução, não faria sentido optar pelo interesse positivo do cumprimento ... por se ter desistido do contrato é puramente formal e conceitual. Com efeito, o incumprimento acarreta danos. Perante eles, há que prever uma indemnização integral. A pessoa que resolva o contrato apenas tenciona libertar-se da prestação principal que lhe incumbe: não pretende, minimamente, desistir da indemnização a que tenha direito. A regra é, pois, sempre a mesma, simples e justa: o incumprimento, que se presume culposo, obriga a indemnizar por todos os danos causados. Ficarão envolvidos danos negativos ou de confiança e danos positivos ou do cumprimento, cabendo, caso a caso, verificar até onde vão uns e outros, sem duplicações e descontando a contraprestação de que a parte fiel fique liberta. ${ }^{, 32}$

\footnotetext{
31 “(...) a verdade é que uma irrestrita retroactividade da resolução poria evidentemente em causa, não só o fundamento de uma indemnização por não cumprimento, como, mesmo, o fundamento da resolução, isto é, a existência de um não cumprimento, já que o parâmetro contratual teria desaparecido ex tunc (...). A contemplação da retroactividade da resolução por não cumprimento é, pois, justificada porque um efeito retroactivo ilimitado iria contrariar o fundamento e a própria finalidade da resolução (que é reagir a um inadimplemento, afastando as suas consequências sobre o sinalagma contratual)". (Paulo Mota Pinto, ob. cit. p. 1645)

${ }^{32}$ Ob. Cit, p. 163
} 
Diante dessas constatações, defendeu-se uma nova leitura, segundo a qual a resolução não opera a aniquilação do contrato, mas, sim, a transformação deste. Transforma-se a relação contratual inadimplida em uma relação de liquidação voltada a preservar o sinalagma e, por conseguinte, a preservar a posição em que o credor estaria não fosse o inadimplemento (a quebra do sinalagma) pelo devedor, ou seja, se o contrato tivesse sido cumprido. ${ }^{33}$

Por fim, em contraponto à alegação de que a cumulação do interesse positivo com a resolução deixaria o credor em situação mais vantajosa do que aquela em que ele estaria com o cumprimento, Paulo Mota Pinto explica, em apertadíssima síntese, que, como se verá no capítulo 2.2.2., não se pode confundir o sinalagma das prestações contratuais, objeto da restituição, com a indenização, que visa ressarcir os prejuízos. ${ }^{34}$

Embasado nesse novo posicionamento introduzido no direito português por Paulo Mota Pinto, o Supremo Tribunal de Justiça lusitano, a partir de 2010, reviu o seu posicionamento há muito consolidado e passou a relativizar o entendimento tradicional, admitindo a cumulação do pedido de resolução com o de indenização pelo interesse contratual positivo, desde que não acarrete, no caso concreto, desequilíbrio contratual, o que deve ser verificado na análise das peculiaridades de cada caso. ${ }^{35}$

Essa breve incursão no estudo de alguns ordenamentos jurídicos estrangeiros revela, como bem apontou Paulo Mota Pinto em sua obra que conduziu à mudança de entendimento do STJP, "que a posição que veda ao credor

\footnotetext{
${ }^{33}$ Paulo Mota Pinto, ob. Cit., pp. 1627-1628.

${ }^{34}$ Ob. Cit, p. 1648.

35 “A indemnização pela destruição da relação contratual, por efeito da resolução, não está limitada ao interesse contratual negativo, podendo ainda abranger, em certos casos, os danos positivos, o interesse contratual positivo, desde que não tal acarrete qualquer situação geradora de desequilíbrios ou benefícios injustificados" (STJ, Processo $n^{\circ}$ 1285/07.7TJVNF.P1.S1, 7 ${ }^{\text {a }}$ Seção, Rel. Conselheiro Barreto Nunes, j. 21.10.2010 (fonte: http://www.dgsi.pt/jstj.nsf/954f0ce6ad9dd8b980256b5f003fa814/37180c4a455437828025782300 3f25a6? OpenDocument)

A posição foi reiterada em recurso de revista julgado em maio de 2018, cuja ementa contou com a seguinte redação: "A resolução do contrato é compatível com a indemnização pelo interesse contratual positivo, que só não será admitida quando revele desequilíbrio grave na relação de liquidação ou se traduza em benefício injustificado para o credor, ponderado à luz do princípio da boa fé, hipótese em que se indemnizará antes pelo interesse contratual negativo"
} 
que resolve o contrato exigir simultaneamente uma indenização por não cumprimento se encontra em claro recuo, estando hoje quase isolada" 36 .

\subsection{O debate doutrinário no Direito brasileiro}

O debate acerca da cumulatividade do pedido resolutório com o de indenização pelo interesse positivo no interesse brasileiro gira em torno da extensão dos efeitos da resolução contratual à luz dos arts. 475, 182, 402 e 944 do $\mathrm{CC}$, notadamente devido ao conceito aberto deixado pelo legislador ao definir, no art. 402 da lei civil, que as perdas e danos, mais especificamente os lucros cessantes, abrangem o que o credor "razoavelmente" deixou de lucrar.

O referido dispositivo, ao qual o art. 475 da lei civil implicitamente remete o intérprete, não definiu objetiva e expressamente a abrangência dos lucros cessantes, deixando ao aplicador do direito a missão de determinar o que poderia ser considerado razoável a título de lucros cessantes.

Diante dessa lacuna, a divergência havida no direito estrangeiro acabou se verificando, também, em território nacional. De um lado, há quem diga ser ilógica e incompatível tal cumulação (corrente tradicional). De outro, quem defende que a legislação brasileira não veda a cumulação da resolução com a indenização pelo interesse positivo (corrente moderna).

A parcela da doutrina brasileira que se alinha à primeira posição acima mencionada invoca os seguintes argumentos: (i) os efeitos da resolução somados ao interesse positivo configurariam um verdadeiro benefício à parte lesada, ultrapassando os limites da reparação integral estabelecidos pelo art. 944 do CC; (ii) aplica-se por analogia o art. 182 do CC que impõe a restituição da partes ao status quo ante em caso de resolução, situação incompatível com o acréscimo patrimonial que seria auferido com o contrato; (iii) os efeitos da resolução contratual retroagem plenamente, extinguindo o contrato desde a sua origem ${ }^{37}$, liberando os contraentes de eventuais prestações pendentes (efeito liberatório) e garantindo a eles o direito de reaver as parcelas pagas (efeito restitutório), o que significa que ambos os contraentes devem retornar ao estado em que se

\footnotetext{
${ }^{36}$ Paulo Mota Pinto, op. cit., p. 1638.

${ }^{37}$ Exceção feita aos contratos duradouros, cujos efeitos são apenas prospectivos.
} 
encontravam como se o contrato não tivesse existido; (iv) consequentemente, nesse cenário, admitir que o credor, além de receber de volta a parte da sua prestação que fora entregue ao devedor, cumulativamente, ainda receba deste o acréscimo patrimonial contratual que auferiria com o contrato, implica em colocálo em situação melhor do que estaria se o contrato tivesse sido adequadamente cumprido, caracterizando o seu enriquecimento injustificado e desequilíbrio contratual (quebra de sinalagma); (v) ao resolver o contrato, a parte desiste do mesmo, razão pela qual é incoerente que venha postular indenização pelo seu cumprimento; e, por fim, (vi) o interesse positivo possui caráter substitutivo ao cumprimento, o que não se harmoniza com a extinção do contrato.

Já aqueles que se alinham ao entendimento moderno capitaneado pelo jurista português Paulo Mota Pinto baseiam-se nos seguintes argumentos: (i) além da cumulatividade estar prevista na Convenção de Viena sobre Contratos de Compra e Venda Internacional de Mercadorias (CISG) ${ }^{38}$, que possui força de lei no Brasil ${ }^{39}$, as amplas disposições dos arts. 402 e 475 do CC, cuja redação não limita o dano indenizável como fazem outros artigos do Código (e.g. art. 443 ${ }^{40}$ ), leva a crer que neles estão contemplados tanto o interesse positivo, quanto o negativo, sem espaço à interpretação restritiva proposta pela corrente tradicional; (ii) é descabida a aplicação analógica do art. 182 do $\mathrm{CC}$, pois voltado aos contratos inválidos (nulos ou anulados), situação muito diferente dos contratos que são válidos, mas descumpridos; (iii) o efeito extintivo da resolução se opera apenas quanto às prestações contratuais principais, sem prejuízo ao direito indenizatório, sob pena de se subverter a finalidade da resolução, que é um remédio voltado a proteger o credor, não o devedor; (iv) admitir que o contrato e todos os deveres e obrigações a ele inerentes jamais existiram implica em admitir que o próprio descumprimento contratual e a própria resolução também não ocorreram, o que é absolutamente ilógico; (v) os efeitos liberatórios e restitutórios não se confundem com o direito à indenização e são plenamente conciliáveis, não

\footnotetext{
38 A CISG unifica e regulamenta as condições de formação dos contratos de compra e venda internacional de mercadorias, determina as obrigações do vendedor e comprador, bem como estabelece medidas em caso de perdas e danos por violação contratual e outras formas de descumprimento.

${ }^{39}$ Decreto Legislativo $n^{\circ} 538 / 2012$ e Decreto $n^{\circ} 8.327 / 2014$.

40 “Art. 443. Se o alienante conhecia o vício ou defeito da coisa, restituirá o que recebeu com perdas e danos; se o não conhecia, tão-somente restituirá o valor recebido, mais as despesas do contrato." (g.n.)
} 
havendo que se falar em enriquecimento sem causa, contanto que, no momento da liquidação do dano, seja observada a teoria das diferenças, compensando-se as prestações retidas e/ou restituídas com o benefício contratual que seria auferido pela parte (interesse positivo); (vi) o argumento de que a resolução implica na desistência do contrato, incompatível, portanto, com a indenização pelo seu cumprimento (interesse positivo) é que é ilógico, porquanto usa, em desfavor do credor, limitando o seu direito indenizatório, um remédio preventivo (a resolução) que é feito justamente para resguardá-lo; (vii) ao resolver o contrato, o credor almeja apenas liberar-se das prestações contratuais, desfazendo-se do vínculo contratual, até mesmo, para evitar o agravamento da sua situação, não há renúncia e ela não pode ser tacitamente considerada; e, por fim, (viii) além da reconhecida dificuldade prática em se liquidar o lucro cessante no âmbito do interesse negativo, historicamente, o dano negativo está mais próximo à responsabilidade pré-contratual, ao passo em que o dano positivo, por se relacionar à execução do contrato, está mais próximo à responsabilidade contratual, razões pelas quais este último deve ter primazia sobre aquele, mesmo em caso de resolução contratual.

É o que se verá mais pormenorizadamente nos subtópicos seguintes.

\subsubsection{Corrente contrária à indenização pelo interesse positivo em caso de resolução contratual}

Um dos primeiros juristas a estudar os institutos em questão com mais profundidade, Araken de Assis ${ }^{41}$ afirma que, por força da aplicação analógica do art. 182 do CC, que trata dos efeitos advindos da anulação do negócio jurídico, a resolução contratual possui o efeito de restituir as partes ao status quo ante, retroagindo integralmente os efeitos extintivos da resolução até à data de celebração do contrato.

Com isso, não é razoável que o contraente lesado retenha a sua parte da prestação contratual em seu patrimônio e, adicionalmente, incorpore a ele o capital que obteria se tivesse a entregado à contraparte. Ao analisar um caso

${ }^{41}$ Diz ele: "Corolário natural e óbvio da extinção, assim produzida, consiste no retorno dos parceiros às posições ocupadas antes da contratação. É o que determina o art. 182 do CC-02 relativo à ação de nulidade, mas aplicável analogicamente ao remédio resolutivo, quando dispõe: 'restituir-se-ão as partes ao estado, em que antes dele se achava, e não sendo possível restitui-las, serão indenizadas pelo equivalente." (in Resolução do contrato por inadimplemento. 5. ed. São Paulo: Ed. RT, 2013; p. 142) 
concreto julgado pela e. $4^{\mathrm{a}}$ Turma do $\mathrm{STJ}^{42}$, o jurista gaúcho pondera, ainda, que, do ponto de vista da parte inadimplente "os efeitos se afiguram dramáticos: ficará sem o bem e desfalcado de parte do respectivo preço" ${ }^{43}$, ou seja, retornará a uma posição pior a que estava antes do contrato.

$\mathrm{Na}$ sua leitura, seria evidente a total incompatibilidade lógica entre o interesse positivo e a eficácia extintiva do remédio resolutório, pois não haveria como situar o credor em posição equivalente à que resultaria do cumprimento se o contrato foi destruído retroativamente, devendo ser tido como se jamais tivesse existido.

Por isso, afirma que "o art. 475 do CC-02 contempla o chamando 'interesse negativo", 44 e que a valorização do bem ou o acréscimo que seria obtido caso o contrato fosse cumprido (i.e. o interesse positivo) configura efeito hipotético, vetado no ordenamento jurídico pátrio, de modo que, consoante doutrina de Antônio Junqueira Azevedo: "O que razoavelmente deixou de lucrar não é, naturalmente, o que obteria com o contrato, e, sim, o que obteria se as negociações não fossem realizadas" $" 45$.

Ou seja, na perspectiva do insigne autor, a intepretação conjunta dos arts. 182, 475 e 402 do CC não permite a cumulatividade defendida pela vanguarda europeia, pois, o primeiro dispositivo citado estende ao máximo a eficácia repristinatória da resolução (art. 182), que, por sua vez, é incompatível com a inclusão do interesse positivo na indenização pelos lucros cessantes devidas ao credor (art. 475). Ou seja, ele não pode ser reparado por aquilo que razoavelmente lucraria com o contrato resolvido (art. 402), mas apenas com o que deixou de lucrar com outros contratos não celebrados em função do pacto inadimplido.

Essa posição também encontra amparo na doutrina de Judith MartinsCosta $^{46}$ e Gisela Guedes ${ }^{47}$.

\footnotetext{
${ }^{42}$ Resp 109.174/SP, Rel. Min. Ruy Rosado, j. 20.02.97

${ }^{43}$ Ob. Cit, p. 147

${ }^{44}$ Ob. Cit, p. 146

${ }^{45}$ Idem, pp. $147-148$

${ }^{46}$ In Responsabilidade civil contratual. Lucros cessantes. Resolução. Interesse positivo e interesse negativo. Distinção entre lucros cessantes e lucros hipotéticos. Dever de mitigar o próprio dano. Dano moral e pessoa jurídica, in: Renan Lotufo, Giovanni Ettore Nanni e Fernando Rodrigues Martins (orgs.), Temas relevantes de direito civil contemporâneo, São Paulo: Atlas, 2012

${ }^{47}$ GUEDES, Gisela Sampaio da Cruz. Lucros cessantes: do bom senso ao postulado normativo da razoabilidade, São Paulo: RT, 2011, pp. 125-148
} 
Em parecer sobre disputa arbitral envolvendo os critérios para o cálculo dos lucros cessantes em razão da resolução de contrato de joint venture para construção e exploração de hotéis pelo prazo de 15 anos, além das questões acima, Judith Martins-Costa, acrescenta ao debate (i) o princípio da reparação integral insculpido no art. 944 do CC; e (ii) o "caráter substitutivo" da indenização pelo interesse positivo e sua incompatibilidade com os efeitos da resolução, que gera uma "obrigação de restituir".

Para a parecerista, o cálculo dos lucros cessantes orbita em torno do brocardo tout le dommage, mais rien que le dommage, expresso no caput do art. 944 do Código Civil, cuja intepretação deve ser no sentido de resguardar a reparação dos prejuízos injustamente sofridos, sem que isto, entretanto, configure o enriquecimento sem causa da vítima, "não se admitindo, como diz BÉNABENT, que [o lesado] receba um 'verdadeiro benefício' ao invés de uma compensação". ${ }^{48}$

Como o interesse positivo visa estabelecer a situação hipotética patrimonial na qual o lesado estaria se o contrato houvesse sido cumprido, sustenta ela que a indenização nele baseada possui "caráter substitutivo ao cumprimento da obrigação principal"49. Está, portanto, atrelado aos casos em que o contraente lesado postula o cumprimento forçado do contrato e, ante o insucesso deste, aí sim, substitui a obrigação principal pelo recebimento da indenização equivalente (pelos lucros que auferiria com o contrato). O interesse, aqui, é pelo cumprimento e, em substituição deste, pela respectiva indenização, que não pode ser pleiteada se a parte desistir do contrato. ${ }^{50}$

Já a indenização pelo interesse negativo, por seu turno, por visar restabelecer a situação em que o credor se encontraria antes do contrato, dialoga com a hipótese de resolução contratual, cujo efeito é justamente "fazer com que as partes retornem, na medida do possível, ao seu estado anterior, resultando, portanto, em obrigação de restituir" $"$ 1.

Assim, considerando (a) o caráter substitutivo do interesse positivo e (b) o caráter restitutório do interesse negativo, bem como visto acima que (c) a

\footnotetext{
${ }^{48}$ Ob. Cit, item 3, p. 562.

${ }^{49}$ Judith Martins-Costa, ob. Cit., item 4, p. 562.

${ }^{50}$ Idem, p. 565. Nesse sentido também: Gisela Guedes, ob. cit, p. 139.

${ }^{51}$ Ibidem, item 6, p. 563.
} 
reparação integral resguarda o direito à compensação, mas não o direito a um benefício extra; afirma a autora não ser viável cumular a resolução com o interesse positivo, restando à parte lesada a escolha de uma dentre as seguintes opções:

“(a) ou exige o cumprimento específico da prestação e, não sendo mais este possível, pede uma indenização por perdas e danos pelo interesse positivo (ou 'interesse do cumprimento'); mantendo-se, pois vinculado à sua prestação e não recebendo de volta o preço eventualmente já pago pela coisa; ou, inversamente, (b) pleiteia a resolução do contrato, liberando-se de cumprir, recebendo de volta o já pago e recebendo perdas e danos pelo interesse negativo." 52

Arremata, então, que, em se tratando de resolução contratual (art. 475 do CC), a expressão "razoavelmente deixou de lucrar", prevista no art. 402 do CC, não deve abranger aquilo que o credor obteria com o cumprimento do contrato (interesse positivo), e, sim, o que obteria se não tivesse confiado na eficácia do contrato (interesse negativo). ${ }^{53}$

Por fim, para além das questões acima expostas, Gisela Guedes ${ }^{54}$, em sua obra sobre as perdas e danos, também destaca que com a resolução o credor almeja a exoneração da obrigações contratuais, com a reposição do seu patrimônio ao estado anterior ao contrato, tal qual conceitua o interesse negativo, liberando-se para que possa retornar ao mercado em procura de outro parceiro negocial, mantendo, assim, o sinalagma contratual.

Verifica-se, portanto, que a doutrina brasileira contrária à cumulatividade do interesse positivo com a resolução do contrato incorpora no direito nacional as mesmas premissas adotadas pela corrente tradicional lusitana, apegando-se, sobretudo, a uma alegada incompatibilidade entre os efeitos da resolução e o interesse no cumprimento do contrato.

\subsubsection{Corrente favorável à indenização pelo interesse positivo em caso de resolução contratual}

Assim como a corrente tradicional, também a posição que pugna pela indenizabilidade do interesse positivo em caso de resolução contratual é

\footnotetext{
52 Judith Matins-Costa, ob. cit, p. 563; g.n.

${ }^{53}$ Idem, p. 565

${ }^{54}$ Ob. Cit., pp. 133-134
} 
referendada por respeitáveis vozes da doutrina pátria, tais como: Pontes de Miranda ${ }^{55}$, Orlando Gomes, Ruy Rosado, Nelson Rosenvald e Cristiano Chaves, Paulo Jorge Scartezzini e Renata Steiner, em grande parte com arrimo na doutrina europeia, mas com enfoque nos dispositivos do Código Civil brasileiro aplicáveis.

As primeiras ponderações sobre o tema foram feitas por Pontes de Miranda que, ao comentar o $\S$ único do art. 1.092 do CC16 (equivalente, mutatis mutandis, ao atual art. 475 do (C), fez um contraponto aos dispositivos alemão e suíço (que, à época não admitiam o interesse positivo em caso de resolução contratual) e afirmou, categoricamente, que "o direito brasileiro admite que se levem em conta o interesse negativo e o positivo" e que, aqui, as perdas e danos contemplam "o que se deixou de ganhar por faltar a eficácia ao negócio jurídico". In verbis:

"Perdas e danos, no art. 1.092, parágrafo único, do Código Civil são o que se deixou de ganhar e que se sofreu com a diminuição do que se tem, bem como o que se deixou de ganhar por faltar a eficácia ao negócio jurídico.

(...)

Mas, à diferença do direito alemão e do suíço, o direito brasileiro admite que se levem em conta o interesse negativo e o positivo (tomo XXV, \$3.091). No direito brasileiro, não se indeniza só o que concerne ao interesse negativo, como em direito suiço. $O$ que o contraente ou pré-contraente deixou de ganhar também é indenizado. Toma-se por base, por exemplo, o que valeria no momento da prestação da indenização, o bem a ser prestado. O que se indeniza é o dano que resultou de se ter tornado sem efeito o que se cria que teria efeito." 56

Também Orlando Gomes, embora de forma ainda mais breve, afirmou que a resolução provocada pela inexecução contratual culposa admite a cumulação, apurando-se a indenização com base na teoria das diferenças. ${ }^{57}$

Mais recentemente, o tema foi estudado mais a fundo por Ruy Rosado, que, ao interpretar a literalidade dos arts. 475 e 402 do CC, afirmou que "as

\footnotetext{
${ }^{55}$ Há quem diga que Pontes de Miranda seria contrário à cumulatividade. Não nos parece ser essa, entretanto, a melhor leitura da doutrina do tratadista, pelos motivos que serão abordados adiante.

${ }^{56}$ Pontes de Miranda, Tratado de direito privado - Parte especial. 2. ed. Rio de Janeiro: Borsoi, 1962. t. XXXVIII, p. 340.

57 “A resolução por inexecução culposa não produz apenas o efeito de extinguir o contrato para o passado. Sujeita ainda o inadimplente ao pagamento de perdas e danos. A parte prejudicada pelo inadimplemento pode pleitear a indenização dos prejuízos sofridos, cumulativamente com a resolução. Embora algumas legislações disponham que não podem ser pedidas conjuntamente, o Direito pátrio, seguindo orientação do suíço, admite a cumulação. (...) As perdas e danos abrangem a dammum emergens e o lucrum cessans. A obrigação de indenizar regula-se na sua liquidação, pelos princípios traçados na Differenz theorie, segundo as quais se calculam pela diferença de valor entre a prestação e a contraprestação que se tornou inexigível." (Contratos. 25. Ed. Atual. Humberto Theodoro Junior, Rio de Janeiro: Forense, 2002, p. 177; g.n.)
} 
amplas disposições" das referidas normas permitem concluir o acolhimento também do interesse positivo:

"O art. 475 do CC garante ao não inadimplente o direito de indenização por perdas e danos; 'perdas e danos', diz o art. 402 do CC, salvo exceção expressaque não é o caso - abrangem, além do que o credor efetivamente perdeu (despesas, preparação para a celebração e cumprimento do contrato etc.), o que razoavelmente deixou de lucrar, nessa parcela compreendido também o ganho que não teve em razão do incumprimento e da resolução. Nessas amplas disposições estão inseridas as vantagens que o credor não inadimplente auferiria com o recebimento da prestação." 5859

Nesse mesmo sentido se manifestou Paulo Scartezzini quando rebateu o "caráter substitutivo" do interesse positivo. Com base em uma interpretação literal do art. 475 do $\mathrm{CC}$, combinada com uma leitura sistemática e comparativa com outros dispositivos legais inserido no Código Civil, o saudoso civilista e magistrado paulista sustentou que a melhor interpretação do dispositivo legal seria a não restritiva, por absoluta ausência de qualquer indicação textual nesse sentido. In verbis:

"Não vemos no art. 475 do CC, como o fazem esses autores, uma diferença no tipo de interesse tutelado (dano indenizável), seja quando se postula a resolução do contrato, seja quando se pleiteia o cumprimento da obrigação. Data maxima venia, não se observa, como pretende a professora Judith Martins-Costa, o alegado 'caráter substitutivo' do interesse contratual positivo; se o objetivo da norma fosse restringir o dano a ser indenizado teria, como fez nos arts. $182 \mathrm{ou}$ 443 (no caso de culpa), ambos do CC, deixado isso claro. A interpretação restritiva feita não encontra, a nosso ver e com todo respeito, respaldo nas regras de hermenêutica e se afastam, como vimos e ainda veremos, da orientação que tem prevalecido nos principais ordenamentos jurídicos. ${ }^{60}$

Não fosse a falta de qualquer restrição do $\mathrm{CC}$, a cumulatividade defendida por essa corrente também encontra guarida na expressa redação dos arts. 75 e 76 da CISG $^{61}$, que passaram a ter força de lei no Brasil com a promulgação do

\footnotetext{
58 Comentários ao novo Código Civil - Da extinção do contrato. Coord. Sálvio de Figueiredo Teixeira. Rio de Janeiro: Forense, 2011. vol. 6, t. II, p. 706-707

${ }^{59}$ A mesma interpretação literal é feita por Nelson Rosenvald e Cristiano Chaves: "Na resolução por causa imputável ao devedor, o ressarcimento compreenderá os interesses positivos e os interesses negativos. (...) No Código Civil (art. 402), a amplitude da expressão 'perdas e danos' abrange, além do que efetivamente se perdeu, o que razoavelmente se deixou de lucrar, nesta parcela também compreendido o ganho que não se teve em razão do incumprimento e da resolução. Nessas amplas disposições estão inseridas as vantagens que o credor não inadimplente auferiria com o recebimento da prestação." (Op. Cit., p. 551-552)

${ }^{60}$ Ob. Cit, p. 11

${ }^{61}$ Artigo 75 "Se o contrato for rescindido e se, em modo e prazo razoáveis após a rescisão, o comprador proceder a uma compra substitutiva ou o vendedor a uma venda substitutiva, a parte que exigir a indenização poderá obter a diferença entre o preço do contrato e o preço estipulado
} 
Decreto Legislativo $n^{\circ} 538 / 2012$ e Decreto $n^{\circ} 8.327 / 2014$, e contemplam a indenização por pelo interesse positivo em caso de resolução do contrato, apurado de acordo com a teoria das diferenças. ${ }^{62}$

No que tange ao efeito ex tunc extintivo do contrato, operado pela resolução, Ruy Rosado afirma que atinge apenas a prestação principal e os deveres acessórios, dos quais são liberadas as partes, mas não extingue a relação global, sobre a qual se fundamenta o dever de restituir e indenizar. ${ }^{63}$

Seguindo a doutrina de Larenz, sustenta o autor que a relação obrigacional principal das partes é extinta apenas em parte, sendo a parte remanescente substituída por uma relação de liquidação, na qual deve ser apurada a indenização. E arremata: "Se todo o contrato fosse tido como um nada, desapareceria o próprio incumprimento, que só é reconhecível pelo exame e confronto entre o que foi contratado e o comportamento posterior das partes; sem contrato, não haveria (ou não poderia haver) o ilícito". ${ }^{64}$

Ademais, como bem observa Renata Steiner, a simples liberação das partes ou restituição do credor ao status quo ante não produz efeitos indenizatórios diretos. Em outras palavras, voltar o credor a sua situação originária, embora o coloque em situação menos lesiva (indenizando-o indiretamente), não repara

na operação substitutiva, assim como quaisquer outras perdas e danos exigiveis de acordo com o artigo 74." (g.n.)

Artigo 76 "(1) Se o contrato for rescindido e as mercadorias tiverem preço corrente, a parte que exigir a indenização das perdas e danos poderá, se não houver procedido à compra substitutiva ou à venda substitutiva previstas no artigo 75, obter a diferença entre o preço fixado no contrato e o preço corrente no momento da resolução, bem como quaisquer outras perdas e danos exigíveis em razão do artigo 74. Não obstante, se a parte que exigir a indenização houver resolvido o contrato após ter tomado posse das mercadorias, aplicar-se-á o preço corrente no momento de tomada de posse, em lugar do preço corrente no momento da rescisão. (2) Para os fins do parágrafo anterior, o preço corrente será aquele do lugar onde a entrega das mercadorias deveria ter sido efetuada ou, na falta de preço corrente nesse lugar, o preço praticado em outra praça que puder razoavelmente substituí-lo, levando-se em consideração as diferenças no custo de transporte das mercadorias." (g.n.)

${ }^{62}$ Renata Steiner, Ob. Cit., pp. 302-304

63 "Mais aceitável, porém, na perspectiva dinâmica da obrigação, considerar-se, como LARENZ, que a relação obrigacional não fica totalmente anulada, persistindo dela os deveres de diligência $e$ de indenização de danos. (...) Logo, o efeito extintivo retroativo da resolução atinge a prestação principal e os deveres acessórios, liberando ambas as partes, mas não extingues a relação contratual global, sobre que se fundamentam o dever de restituir e o de indenizar." Extinção dos contratos por incumprimento do devedor, Ob. Cit., p. 259

${ }^{64}$ Idem, p. 266 
aquilo que ele deixou de ganhar por culpa da parte infratora. ${ }^{65}$

Consequentemente, o mero efeito liberatório, assim como restitutório da resolução, não podem prejudicar o direito à indenização, estando, assim, adstritos às prestações contratuais, sem implicar em renúncia ao direito da parte lesada à indenização pelo cumprimento; obrigação da parte infratora que não é extinta com o fim do contrato.

Nessa mesma linha, Renata Steiner acrescenta que "o descumprimento é uma situação patológica"66, cujo remédio preventivo, colocado à disposição da parte lesada para mitigar o risco do inadimplemento ${ }^{67}$, é a resolução. Logo, o efeito desconstitutivo produzido pela resolução vem em favor do interesse do credor, não podendo ser confundido como uma sanção a ele, consistente na renúncia ao direito de receber a indenização com base no cumprimento do contrato. Ao contrário, se sanção há, por lógica, essa se volta exclusivamente em desfavor do credor $^{68}$, até porque, a extinção do contrato, embora coloque fim ao inadimplemento, não o sana e tampouco o retira do mundo jurídico. Se a causa da resolução não deixa de existir, por ela o devedor continua a ser responsável. ${ }^{69}$

Admitir o contrário, como faz a corrente tradicional, seria o mesmo que admitir que o remédio, na verdade, não seja ministrado em prol do paciente, mas, sim, da doença.

Paulo Scartezzini faz, ainda, um interessante contraponto à posição adotada por Araken de Assis acerca da aplicação analógica do art. 182 do CC. Embora concorde com o descabimento da indenização pelo interesse positivo ${ }^{70}$ nos casos de um contrato nulo ou anulado (inválido, portanto), o saudoso magistrado paulista refutou a aplicação analógica daquela regra aos contratos que, apesar de serem perfeitos, não foram cumpridos por um dos contraentes, já que,

\footnotetext{
${ }^{65} \mathrm{Ob}$. Cit, pp. 288-289. Por isso é que a civilista das arcadas, mais adiante, sustenta que a relação de liquidação iniciada pela resolução contratual é composta por 3 etapas distintas: liberatória, restitutória e indenizatória. (Op Cit., p. 295)

${ }^{66}$ Idem, p. 282

67 "Veja-se, por exemplo, a nítida vantagem do caráter liberatório quando for possível contratar com um terceiro para cumprimento da obrigação ajustada, circunstância que se mostra eficiente à tutela contra o descumprimento em favor do credor lesado. Ao contrário, manter o credor vinculado significaria, muitas vezes, incrementar o dano causada pela falta de cumprimento do contrato, situação que muitas vezes irá perdurar.” Ibidem, p. 288

${ }^{68}$ Idem, p. 282.

${ }^{69}$ Ibidem, p. 283.

${ }^{70}$ Ob. Cit, p. 8 .
} 
nesse caso, "o contrato existiu, é válido, porém não foi levado a termo pelo devedor. As consequências jurídicas e práticas devem ser diversas das hipóteses de nulidade absoluta ou relativa" $"$.

E arremata dizendo que " $[\mathrm{m}]$ esmo no direito português, em que há norma expressa afirmando que a resolução, como regra, tem seus efeitos equiparados aos da nulidade e da anulabilidade, não se faz essa interpretação."72

De acordo com essa corrente, portanto, ilógico seria se admitir a completa aniquilação do contrato do mundo jurídico e, junto com ela, o direito à integral reparação, pois tal compreensão, (i) além de não encontrar respaldo na legislação positiva pátria (nem mesmo analogicamente), (ii) culmina na extinção do próprio ilícito que ensejou a resolução e (iii) subverte a finalidade desta última, que é de ser um remédio voltado a tutelar o interesse da parte lesada, não o da inadimplente.

Destarte, embora se admita o efeito retroativo da extinção contratual, é preciso dosá-lo, limitando a sua extensão apenas às prestações contratuais, de modo a não prejudicar a parte que o deflagrou, que é quem justamente demanda a tutela reparatória.

Resta pendente, então, o argumento de que o credor que retivesse as suas prestações e ainda recebesse o lucro contratual enriqueceria sem causa.

Sobre o ponto, primeiramente, Renata Steiner $^{73}$ esclarece com maestria que não há ofensa ao sinalagma contratual e tampouco nada de ilógico entre o credor optar por não prosseguir com o contrato descumprido (resolvendo-o) e, em seguida, buscar os lucros que com ele auferiria.

Isso porque o sinalagma se dá no âmbito das prestações intracontratuais. Assim, de fato, não pode o credor resolver o contrato e, em seguida, buscar a contraprestação com a qual, no âmbito daquele, comprometera-se a outra parte. Ao resolver o pacto, o credor se libera da obrigação de prestar (e obtém o direito de se restituir do que prestou) e, portanto, não pode exigir nenhuma prestação contratual da parte contrária.

\footnotetext{
${ }^{71}$ Idem, p 11.

${ }^{72}$ Ibidem, p. 11.

${ }^{73}$ Ob. cit, pp. 292-293.
} 
Não é disso, porém, que se trata o interesse positivo. O credor não almeja receber o equivalente à prestação descumprida, mas, sim, o equivalente aos prejuízos sofridos pelo descumprimento dela, que, em termos objetivos, corresponde ao lucro contratual. O lucro, por sua vez, é um elemento externo ao contrato, que pode, inclusive, sequer existir ${ }^{74}$. Sendo ele externo, não integra, portanto, o sinalagma contratual.

Bem compreendida a lógica jurídica e a ausência de ofensa ao princípio da reciprocidade das prestações, passa-se à etapa de quantificação/liquidação da indenização, cujo exame é imprescindível para se desconstituir o alegado risco de locupletamento injustificado do credor, invocado pela corrente tradicional.

Para solucionar essa questão, surgiu na Alemanha a teoria da "diferença restrita ou atenuada", segundo a qual "o credor, no contrato sinalagmático, teria a opção entre abater do valor indenizatório o valor de sua prestação ou receber integralmente a indenização e cumprir sua prestação ao devedor""75. Assim, "caso o credor não tenha ainda cumprido sua obrigação, basta que se abata do que vier a ser recebido por ele, o valor de sua prestação". ${ }^{76}$

Uma vez realizada essa operação de liquidação, não haveria que se falar em enriquecimento sem causa, pois o valor da contraprestação devida (restituído ou mantida com o credor) é levada em consideração para o cálculo do prejuízo sofrido. ${ }^{77}$ Exemplificativamente:

\begin{abstract}
“A adquire de B uma máquina por $R \$ 10.000,00$, com o objetivo de fabricar camisas. A paga o preço e não recebe a coisa. A então pede a resolução do contrato (o que significa que o devedor deverá restituir o valor recebido) e uma indenização pelo que deixou de lucrar ao não produzir e vender as camisas. Ora, provado o prejuízo (lucro cessante, dentro dos limites do art. 403 do CC), o vendedor, se já devolveu o preço ao comprador, abaterá do valor a ser indenizado ao comprador aquela importância (R\$10.000,00); se
\end{abstract}

\footnotetext{
${ }^{74}$ Pense, por exemplo, em uma empresa que opera de forma ineficiente e deficitária. Ou, então, quando o contrato tem por objeto um empreendimento inovador, cujo êxito é futuro e incerto, de difícil verificação. Nessas hipóteses, ainda que fosse reconhecido o direito à indenização pelo interesse positivo, ao liquidá-lo, ver-se-ia que o credor lesado não faria jus a nada, seja porque, na primeira hipótese, o análise da sua contabilidade pregressa revela que o contrato descumprido não lhe traria lucro, seja porque, na segunda hipótese, se está diante de um lucro hipotético, sem mínima base para sustentar sua efetividade, tal qual prescreve o art. 403 do CC.

${ }^{75}$ Scartezzini, ob. cit, p.12. No mesmo sentido, Orlando Gomes, Op. Cit., p. 177 e Renata Steiner, Op. Cit., p. 294. De forma similar, Ruy Rosado afirma que a indenização pelo interesse positivo em caso de resolução "não pode levar à cumulação de parcelas, devendo-se optar pela solução que melhor componha o interesse de ambas as partes, com a predominância para o interesse positivo" (Extinção..., ob. cit., p. 269)

${ }^{76}$ Scartezzini, ob. cit., p. 12.

${ }^{77}$ Renata Steiner, ob. cit, p. 294.
} 
ainda não devolveu, indenizará todo o valor pleiteado." ${ }^{" 78}$

Outra situação facilmente visualizável se dá no caso em que há valorização de imóvel objeto de promessa de compra e venda descumprida pelo promitente vendedor, que se recusa a entregá-lo ao promitente comprador. Nesse cenário, resolvendo-se o contrato, com a restituição das respectivas prestações à cada parte, se o acréscimo patrimonial (valorização do bem) não ficar com o credor, fatalmente beneficiará o devedor. ${ }^{79}$

Diante disso, mostra-se razoável transferir a vantagem ao lesado, pois, do contrário, ter-se-ia o absurdo enriquecimento sem causa justamente da parte inadimplente, que, mesmo após restituir o preço pago pelo promitente comprador, ainda permaneceria com o imóvel, acrescido da respectiva valorização.

Situação similar também foi conjecturada por Paulo Scartezzini ${ }^{80}$, em caso de descumprimento de contrato de compra e venda contendo cláusula penal compensatória (que liquida, portanto, antecipadamente o dano). Resolvendo-se o contrato por culpa do devedor, poderá a credor se restituir o que pagou e ainda cobrar a cláusula penal, que faz as vezes de equivalente ao dano positivo.

É bem verdade que, ante a particularidade de cada caso, pode ser que a aplicação da teoria das diferenças à liquidação do dano não seja tão simples como nas hipóteses acima, uma vez que não existem parâmetros seguros para o cálculo do equivalente ao que a parte obteria com o contrato.

Porém, como explica Renata Steiner ${ }^{81}$, eventuais dificuldades para cálculo do dano contratual positivo não podem ser utilizadas como subterfúgio para se limitar a indenização ao interesse negativo. Além da dificuldade de liquidação do dano não manter uma relação de prejudicialidade com o seu cabimento, ela é verificada tanto no interesse positivo, como, também, para se definir a vantagem que o credor obteria em um contrato alternativo que deixou de lado por conta

\footnotetext{
${ }^{78}$ Scartezzini, ob. cit., pp. 12-13.

79 Ruy Rosado, In Comentários ao Novo Código Civil, volume vi, tomo II: da extinção do contrato. Coord. Sálvio de Figueiredo Teixeira. Rio de Janeiro: Forense, 2011, p. 708, nota de rodapé.

80 "Pensemos no seguinte exemplo: A vende para B um automóvel, com cláusula penal compensatória no valor de $R \$ 10.000,00$. B paga o valor pactuado de $R \$ 50.000,00$, porém A não entrega o carro. Nesse caso, B pode pedir a resolução do contrato, a devolução dos $R \$ 50.000,00$ já pagos e ainda os $R \$ 10.000,00$ de multa" (Ob. Cit.)

${ }^{81}$ Extinção ..., ob. cit., pp. 295-296
} 
daquele inadimplido (interesse negativo).

Aliás, abrindo-se um rápido parênteses sobre este ponto, Ruy Rosado bem notou que "se a indenização se limitasse aos interesses negativos, a normalidade dos casos não ensejaria indenização" ${ }^{" 82}$ devido à dificuldade de se fazer prova do dano negativo, notadamente dos lucros cessantes ${ }^{83}$, “porque se trata de acréscimos que permanecem totalmente hipotéticos, justamente porque foram negligenciados pela confiança suscitada pelo contrato efetivamente estipulado". ${ }^{84}$ Basta se verificar quão difícil é comprovar quanto a parte lesada lucraria com outro contrato que sequer chegou a se formar (lucros cessantes pelo interesse negativo). Inevitavelmente, a liquidação de tal dano negativo esbarraria no óbice do art. 403 do CC.

Em outras palavras, além de serem comuns tanto ao interesse positivo, quanto ao negativo, eventuais entraves na ulterior liquidação do dano, por serem aferíveis a posteriori, não podem servir de pretexto para se obstar, de antemão, o reconhecimento do dever de indenizar, que surge com o descumprimento culposo do pacto.

Assim, eventual dificuldade na compensação proposta pela teoria das diferenças deve ser sanada pelo aplicador do direito em cada situação concreta. Em última análise, tornando-se impossível liquidar o dano, na competente fase de liquidação, reconhecer-se-á a designada "liquidação zero", sem que, repita-se, possa ser invocado, precipitadamente, como fundamento para se afastar o dever de indenizar.

Com efeito, como se pode extrair da doutrina de Nelson Rosenvald e Cristiano Chaves ${ }^{85}$, não há que se falar em enriquecimento sem causa do contratante lesado, pois é possível fazer o controle da quantia a que ele faz jus no momento da liquidação do dano. Assim, enquanto a parte que optar por prosseguir com o contrato, sem se liberar das suas prestações, fará jus aos que os consagrados doutrinadores designaram como "grande indenização", aquela que decidir resolvê-lo receberá uma "pequena indenização", ou seja, uma indenização

\footnotetext{
${ }^{82}$ Extinção ..., ob. cit, p. 268

${ }^{83} \mathrm{Ou}$ seja, pelo lucro que a parte lesada deixou de ter em outras alternativas de negócios que não celebrou com terceiros por confiar no cumprimento do contrato inadimplido.

${ }^{84}$ Comentários ..., ob. cit., pp. 707-708

${ }^{85}$ Ob. Cit., p. 552
} 
deduzida do valor da contraprestação.

Por fim, convém mencionar que a interpretação histórica dos institutos em exame também se revela favorável à cumulatividade com a resolução, já que, como apontado por Ruy Rosado, "o interesse negativo está ligado à culpa in contrahendo, anterior à celebração do contrato, enquanto a indenização por resolução deriva do incumprimento do contrato, isto é, está relacionada ao momento da execução". ${ }^{86}$

E acrescenta, citando Adalberto Pasqualoto, que, no âmbito do contrato, válido e eficaz, "[a] obrigação do devedor é para com o adimplemento”, ou seja, com o interesse positivo, ao passo em que a fase pré-contratual, por ainda não haver uma relação definitiva formada a ser cumprida, está mais próxima ao interesse negativo, devendo a parte que prometeu e não cumpriu reintegrar a outra parte na situação em que estaria se não tivesse confiado na sua palavra. ${ }^{87} \mathrm{Ora}$, de fato, embora, como visto no capítulo 1, a doutrina tenha evoluído para passar a admitir o interesse negativo e positivo na fase contratual, havendo, inclusive, quem defenda também a existência de interesse positivo já na fase précontratual $^{88}$, a perspectiva histórica exposta por Ruy Rosado procede. Afinal, o interesse negativo realmente começou a ser estudado por Jhering como uma forma de diferenciar a responsabilidade oriunda da culpa in contrahendo da contratual.

Como se viu, são muitos, portanto, os fundamentos para se admitir o direito à indenização pelo interesse positivo em caso de resolução contratual. Resta saber como a questão é enfrentada, na prática, pelo Tribunais; assunto que será abordado no capítulo a seguir.

\footnotetext{
${ }^{86}$ Extinção ..., ob. cit., p. 268

${ }^{87}$ Comentários ..., ob. cit., p. 707

${ }^{88}$ CORDEIRO. António Manuel da Rocha e Menezes. Da boa-fé no direito civil, $2^{\mathrm{a}}$ reimpressão. Coimbra: Almedina, 2001, p. 585 apud Renata Steiner, ob. cit., p. 92 e 119
} 


\section{A POSIÇÃO DOS TRIBUNAIS}

\subsection{Introdução}

Nos capítulos anteriores definiu-se o conceito de interesse contratual positivo e negativo e, em seguida, demonstrou-se a divergência doutrinária havida sobre o tema, inclusive, com a superação de velhos dogmas pelo direito lusitano, não obstante os aparentes óbices do direito positivo lá em vigor.

Neste capítulo, analisar-se-á o debate acerca do tema no âmbito jurisprudencial, iniciando com o precedente do Supremo Tribunal de Justiça português julgado no ano de 2010 que serviu de paradigma para a consolidação da mudança de posicionamento até então adota por aquela Corte. Ato contínuo, estudaremos a jurisprudência pátria no âmbito do STJ e de algumas Cortes ordinárias.

O exame é relevante, tanto para mostrar que a posição tradicional, oriunda da doutrina clássica portuguesa e defendida por parcela da doutrina brasileira, já foi superada mesmo naquele país (em que se encontrava arraigada); quanto por revelar curiosa incoerência verificada entre os julgados brasileiro que enfrentam diretamente a questão objeto desse trabalho e aqueles que não o fazem.

\subsection{Paradigmático precedente do Supremo Tribunal de Justiça português}

Até o ano de 2010 predominava no STJP a orientação tradicional no sentido de que a resolução contratual seria incompatível com a indenização pelo interesse positivo. Tal posição mudou a partir do julgamento do Recurso de Revista $n^{\circ} 1285 / 07.7 T J V N F . P 1 . S 1$.

Tratava-se de ação indenizatória por descumprimento de contrato de compra e venda comercial, cujo objeto era a compra, com a finalidade de revenda, pela autora, de peças de vestuário produzidas pela ré, fabricante. Juntamente com a resolução contratual, a autora postulou (a) a devolução da parcela do preço paga relativa às mercadorias não entregues e (b) indenização pelo descumprimento do contrato. 
A primeira e a segunda instâncias portuguesas acolheram em parte a pretensão autoral, reconhecendo a resolução por culpa da fabricante e condenando-a apenas a restituir à compradora o preço das mercadorias. Refutaram, porém, o pedido "b", acima mencionado, por entenderem, respectivamente, não ser ele compatível com a resolução contratual e dizer respeito a dano hipotético, já que o lucro esperado com as revendas dos produtos que não foram entregues poderia não se concretizar por inúmeros motivos inerentes ao risco do negócio e que não poderiam ser transferidos ao fabricante. ${ }^{89}$

A autora recorreu contra o acórdão da Relação, 2 $2^{\mathrm{a}}$ instância lusitana, levando a questão ao Supremo Tribunal de Justiça lusitano.

Após realizar uma análise histórica da legislação portuguesa e reconhecer que a orientação firmada pela origem se alinhava com a doutrina tradicional e jurisprudência dominantes do $\operatorname{STJP}^{90}$ até então, aquela corte seguiu nova posição, no sentido de que "em regra (...) será admissível a cumulação da resolução do contrato com o pedido de indemnização pelo interesse positivo" contanto que não haja "qualquer situação geradora de desequilíbrios ou benefícios injustificados" o

\footnotetext{
89 “A final, a Relação decidiu que o caso não reveste 'a excepcionalidade exigível para obrigar a vendedora da mercadoria a suportar ainda o montante dos lucros esperados com as vendas que essa mercadoria podia trazer à esfera patrimonial da compradora, uma vez que essas vendas poderiam até nem se realizar por falta de clientes, furto, etc; se realizadas, poderia acontecer que o pagamento respectivo poderia não ser feito na totalidade ou em parte; a compradora não procede ao desconto da proporção de despesas com o estabelecimento (salários, rendas, publicidade); tudo riscos próprios da actividade do comerciante, sujeita a álea, que não transferiu para a vendedora da mercadoria, com o contrato resolvido. A lei não transfere riscos para o contrato resolvido. A boa fé não o exige, pelo contrário. A ponderação dos interesses em presença também não', pelo que negou provimento ao recurso." (trecho extraído do acórdão No 1285/07.7TJVNF.P1.S1, 7 ${ }^{a}$ Seção, Rel. Conselheiro Barreto Nunes, j. 21.10.2010, do STJP, fonte: www.dgsi.pt)

90 "Em caso de resolução contratual, a posição clássica, comum a vários autores, é a de que a tutela do direito indemnizatório se resume ao interesse contratual negativo (cfr., entre outros Almeida Costa, Direito das Obrigações, 6. ${ }^{a}$ ed., p. 918; Antunes Varela, Das Obrigações em Geral, vol. II, p. 109; Menezes Leitão, Direito das Obrigações, II, p. 259), tendo sido igualmente essa a posição acolhida por grande parte da jurisprudência do STJ. (...) No entanto a posição, que defendia a incompatibilidade de cumulação entre a resolução do contrato e a indemnização correspondente ao interesse positivo, tornou-se largamente dominante na doutrina, sobretudo com base nos argumentos dos efeitos retroactivos da resolução e da incoerência da posição do credor ao pretender, depois de ter optado por extinguir o contrato pela resolução, basear-se nele para obter uma indemnização correspondente ao interesse no seu cumprimento. E se assim foi na doutrina, também na jurisprudência a orientação foi semelhante, no sentido de computar a indemnização exigida pelo credor como correspondendo ao interesse contratual negativo, não lhe permitindo reclamar uma indemnização pelo interesse no cumprimento, rompendo-se assim com a linha jurisprudencial seguida e defendida no domínio do Código de Seabra."
} 
que deverá ser apurado "caso a caso, consoante o tipo de contrato e o circunstancialismo que o rodeia". 91

Firmada tal posição, o STJP passou, então, à fase de quantificação da indenização, levando em consideração, conforme prescreve a teoria das diferenças, o valor das prestações devidas pela autora/credora. ${ }^{92}$

De forma bastante técnica, a Suprema Corte de Justiça lusitana afastou o posicionamento da Relação de que o dano seria hipotético ${ }^{93}$ e apurou a indenização de acordo com o preço das mercadorias não entregues, observada a margem histórica de lucro da Autora com a revenda e a perda de estoque, comprovados nos autos.

Embora não tenha indicado, no cálculo da liquidação do dano concreto então em exame, o abatimento da contraprestação devida pela autora da respectiva indenização pelo interesse positivo, os fundamentos jurídicos que conduziram o acórdão passaram a servir de paradigma para o direito lusitano, sendo replicados em inúmeros outros julgados até os dias de hoje. ${ }^{94}$

\subsection{Precedentes do Superior Tribunal de Justiça}

Diferentemente do direito europeu, os interesses positivo e negativo não costumam estar no centro do debate de temas contratuais aventados pelos Tribunais brasileiros ao determinar as perdas e danos, de modo que são poucos os precedentes que ventilam expressamente os pontos controvertidos objeto desse trabalho.

O primeiro julgado sobre a matéria de que se tem notícia no STJ foi relatado pelo Ministro Monteiro de Barros, em recurso especial interposto contra acórdão do TJRS, de lavra do então Desembargador Araken de Assis, que, na

\footnotetext{
91 Ibid.

92 "A consideração da situação em que o credor estaria se não se tivesse verificado o não cumprimento é, assim, perfeitamente compativel com a avaliação do prejuízo pela diferença entre o preço do contrato e o preço, seja do mercado de revenda (no caso do dano do comprador que inclua o lucro cessante), seja o do mercado de abastecimento do vendedor (prejuízo do vendedor que inclui o lucro cessante)."

93 "Esta avaliação do prejuízo - que inclui o lucro cessante - (art. 564", n. ${ }^{o} 1$, do CC) baseia-se numa presunção de facto que resultará da verificação de que normalmente o comprador (maxime, se for comerciante) poderia realizar com a coisa o lucro correspondente ao preço da revenda."

94 A título exemplificativo, destaca-se os seguintes processos: Nos 567/11.8TVLSB.L1.S2 (j. 17/05/2018; 7461/11.0TBCSC.L1.1, (j. 15/02/2018); 1725/13.6TVLSB.C1.S1 (j. 24/01/2017); 1004/12.6TJLSB.L1.S1 (j. 09/12/2014)
} 
oportunidade, manteve-se fiel à sua posição doutrinária contrária à cumulatividade do interesse positivo com a resolução contratual. ${ }^{95}$

Tratava-se de ação indenizatória movida por corretora de seguros contra o seu segurado por conta da violação, por parte deste, ao direito de exclusividade daquela em intermediar toda e qualquer nova contratação de seguro no âmbito daquela relação.

O TJRS havia julgado parcialmente procedente o pleito para reconhecer a resolução por culpa do segurado, mas afastou o pedido de perdas e danos por entender que veiculava interesse positivo, o qual, se concedido, colocaria a seguradora em posição melhor do que se o contrato tivesse sido cumprido, notadamente porque a autora, naquele caso concreto em específico, já havia sido indenizada em outra ação envolvendo a mesma questão.

Ao analisar o caso, o STJ reconheceu, com base na doutrina de Pontes de Miranda e Ruy Rosado, que, apesar de ter postulado a resolução, "em princípio, a autora teria direito ao acréscimo que o seu patrimônio teria experimentado caso o contrato tivesse sido inteiramente cumprido"; divergindo, portanto, do TJRS. Em termos concretos, porém, acabou por manter o acórdão combatido por conta da particularidade do pedido formulado pela seguradora, que, na leitura da maioria, veiculava dano não efetivo e indireto, não comprovado. ${ }^{96}$

Em outra oportunidade, agora sob a relatoria do então Ministro Ruy Rosado, a $4^{\mathrm{a}}$ Turma do $\mathrm{STJ}^{97}$, em precedente invocado em outro julgado mais recente daquela Corte ${ }^{98}$, decidiu que "[o] descumprimento do contrato de promessa de compra e venda de imóvel por parte da promitente vendedora leva à indenização do promissário comprador, que tem o direito de receber, além da devolução do preço, a diferença do valor atual do imóvel”".

O cerne da controvérsia, porém, não residia na cumulatividade do interesse positivo (valorização do imóvel) com a resolução, que já havia sido reconhecida

\footnotetext{
${ }^{95}$ STJ, Resp 107.426/RS, $4^{\text {a }}$ Turma, Rel. Min. Barros Monteiro, j. 20.02.2000

96 A seguradora pediu indenização equivalente a todas as comissões decorrentes das apólices de seguros contratadas pelo réu sem a sua intermediação, mas o STJ entendeu "que ela não prestou serviço algum tocante àquelas outras apólices: não despendeu qualquer gasto" razão pela qual não faria jus ao postulado.

${ }^{97}$ STJ, Resp 403.037/SP, $4^{\text {a }}$ Turma, Rel. Min. Ruy Rosado de Aguiar, j. 28.05.2002

${ }^{8}$ STJ, AgRg no AREsp 486.194/BA, $3^{\text {a }}$ Turma, Rel. Min. Marco Aurélio Bellizze Oliveira, j. 04.08 .2015
} 
pelo TJSP no acórdão recorrido, mas, sim, no percentual da valorização do bem a que faria jus o comprador vis a vis o investimento feito por ele. Isso porque, a Corte Paulista entendera que o comprador, que havia adimplido com apenas $10 \%$ do preço do imóvel, deveria receber apenas o percentual correspondente da valorização do bem.

O STJ reformou a acórdão paulista, pois, segundo a unanimidade dos ministros, ante as particularidades do contrato de promessa de compra e venda de imóvel, a resolução por culpa do vendedor impõe o pagamento de indenização ao comprador em quantia equivalente ao valor total do bem, acrescido do lucro que o mesmo teria com o recebimento do imóvel, independentemente do percentual do preço quitado. Do contrário, o próprio vendedor inadimplente se locupletaria, retendo em seu patrimônio o bem, juntamente com o lucro a ele adicionado, os quais, se cumprido o contrato, seriam do comprador. ${ }^{99}$

Por fim, embora a Corte Superior tenha entendido que o sacrifício do credor (que pagou apenas $10 \%$ do preço) não seja um critério para mensuração da indenização pelo interesse positivo, por equidade, utilizou tal fundamento para, ao final, reduzir o quantum. ${ }^{100}$

A despeito dos pouquíssimos precedentes enfrentando diretamente a controvérsia objeto desse estudo, o exame da jurisprudência da Corte Cidadã revela a existência de inúmeros julgados os quais aplicam implicitamente os

\footnotetext{
99 "Na economia daquele contrato, o desfazimento do negócio pela vontade do vendedor, o prejuízo sofrido pelo comprador consistiu na perda resultante da impossibilidade de incorporar ao seu patrimônio o bem objeto do contrato, com o lucro que lhe adviria disso. Com o descumprimento por parte do vendedor, este se beneficia do próprio inadimplemento, pois incorpora para si o lucro que decorreu da extrema valorização do imóvel, o qual iria para o comprador caso o contrato fosse cumprido.

Não se trata de enriquecimento indevido do comprador, mas da justa recomposição do seu patrimônio pelo fato de ficar impedido de se beneficiar com o lucro do negócio avençado."

100 “4. É preciso ponderar, porém, mais um fator, que considero indispensável para uma solução justa e eqüânime em todos os casos. É o seguinte: se para o promissário comprador que pagou a integralidade do preço a sua reparação deve corresponder à diferença entre o que pagou e o valor atual do imóvel, ou o valor pelo qual o promitente vendeu a um terceiro, essa indenização, não pode ser igual para quem pagou apenas $10 \%$, pois o sacrifício deste foi menor. $O$ dado há de servir não para estabelecer a proporcionalidade exata entre o que foi pago e o valor indenizatório, mas certamente deve atuar como redutor da indenização, que seria igual à diferença de valorização do imóvel apenas no caso do preço pago por inteiro. Apenas por isso, estou em reduzir de $20 \%$ o valor a ser pago, correspondente à diferença entre o valor contratado $(R \$ 172.934,00)$ e o valor atual do imóvel $(R \$ 704.965,00)$, quantias referidas no laudo e aceitas na r. sentença (fl. 293)."
} 
conceitos aqui ventilados, mesmo sem fazer expressa referência ao interesse contratual que os fundamenta.

No âmbito da compra e venda de imóveis na planta, por exemplo, para além do dano contratual positivo consistente na valorização do imóvel, é assente o entendimento de que, em caso de inadimplemento da construtora, pode o comprador resolver o contrato e pleitear indenização por lucros cessantes pela não fruição do imóvel durante, consistente, por exemplo, pelos "alugueres que poderia o imóvel ter rendido se tivesse sido entregue na data contratada". ${ }^{101}$

Destarte, nota-se que, tanto nos poucos precedentes acima destacados, em que a divergência doutrinária objeto desse estudo foi expressamente enfrentada, quanto nos demais casos em que se debate a extensão das perdas e danos em meio à resolução contratual por culpa do devedor, a orientação praticada pelo STJ se mantém coerente e alinhada com vertente doutrinária que admite a indenização pelo interesse positivo.

\subsection{Precedentes dos Tribunais Estaduais}

Assim como no STJ, são poucos os casos em que os Tribunais ordinários colocam a cumulatividade do interesse positivo com a resolução contratual no cerne do debate. Nessas raras ocasiões, porém, as Cortes locais, em geral, têm divergido da posição do STJ e se revelado refratárias à cumulatividade dos institutos em estudo, até mesmo em questões já consideradas uniformizadas, como é o caso da compra e venda de imóvel na planta.

Nesse sentido, a despeito da vasta jurisprudência do $\mathrm{STJ}^{102}$ reconhecer, mesmo quando há resolução contratual, o dever de a incorporadora inadimplente indenizar o comprador pelos alugueres que poderia ter auferido com o imóvel se tivesse sido entregue na data contratada (i. e. o interesse positivo) e, inclusive, da

\footnotetext{
${ }^{101}$ REsp 644.984/RJ, $3^{\text {a }}$ Turma, Rel. Min. Nancy Andrighi, DJ 05.09.2005

102 REsp 151175/DF, $3^{\text {a }}$ T., Rel. Min. Waldemar Zveiter, j. 15/12/1998; REsp 644.984/RJ, $3^{\text {a }}$ T., Rel. Min. Nancy Andrighi, DJ 05/09/2005; REsp 953.907/MS, $3^{\mathrm{a}}$ T., Rel. Min Nancy Andrighi, DJe 09/04/2010; AgRg 1.202.506/RJ, $3^{\text {a }}$ T., Rel. Min. Sidnei Beneti, j. 7/2/2012; REsp 955.134/SC, $4^{\text {a }}$ T., Rel. Min. Luis Felipe Salomão, j. 16/08/2012
} 
restituir das parcelas pagas ${ }^{103}$; a e. $2^{\text {a }}$ Câmara de Direito Privado do TJSP, ao julgar a apelação $\mathrm{n}^{\mathrm{o}}$ 1000902.11.2016.8.26.0604, em 18.02.2016, reformou a sentença que acolhia tal orientação e, então, afastou os lucros cessantes pelo não recebimento do bem que haviam sido concedidos ao comprador.

Segundo a maioria votante, a melhor interpretação dos arts. 475 e 402 do $\mathrm{CC}$ é de que "[p]retendendo o credor resolver o contrato, e não exigir seu cumprimento, sem adimplir o restante do preço, só pode pleitear interesses negativos, como se o contrato não houvesse sido celebrado, não fazendo jus ao recebimento de aluguéis pela privação do bem, pois específica de quem pretende o adimplemento bilateral". ${ }^{104}$

Na mesma linha decidiu a e. $4^{\text {a }}$ Câmara de Direito Privado daquela Corte ao afastar o direito do comprador que resolvera o contrato de ser indenizado pela diferença necessária para que ele pudesse adquirir outro imóvel em idênticas condições, ou seja, de ser indenizado pela compra em substituição. ${ }^{105}$

O interesse contratual positivo também foi negado pela Corte bandeirante em caso envolvendo a rescisão de contrato de prestação de serviços c/c perdas e danos. O condomínio autor firmou com as rés contrato de prestação de serviços e de locação de equipamentos para instalação de "portaria virtual", almejando, assim, reduzir o número de empregados que mantinha. ${ }^{106}$

Embora tenha reconhecido o inadimplemento das rés, os julgadores invocaram o princípio da equivalência e o caráter não sancionatório da resolução para concluir que o prejuízo não pode incluir "o valor que o contrato proporcionaria", interesse positivo não indenizável.

Acrescentaram, ainda, (i) que o condomínio autor não deixou de lucrar com o contrato, mas, sim, de economizar as despesas de pessoal que seriam reduzidas com a implantação da portaria virtual; e (ii) que o autor poderia

\footnotetext{
${ }^{103}$ Essa cumulatividade entre interesse positivo e negativo, sem o devido abatimento sugerido pela teoria das diferenças, como visto no capítulo 2.2.2., é questionável. Entretanto, não adentraremos nessa questão, pois, embora relevante, foge ao cerne do presente trabalho.

104 TJSP, Ap. Civ. 1000902.11.2016.8.26.0604, 2a Câmara de Direito Privado, Rel. Des. Alcides Leopoldo e Silva Júnior, j. 28.03.2017

105 TJSP, Ap. Civ. 0956252-18.2012.8.26.0506, $4^{\text {a }}$ Câmara de Direito Privado, Rel. Des. Hamid Bdine, j. 18.02.2016

106 TJSP, Ap. Civ. 1005260-52.2016.8.26.0011, 34ª Câmara de Direito Privado, Rela. Desa. Maria Cláudia Bedotti, j. 11.04.2018
} 
contratar outra empresa que prestasse o mesmo serviço para lograr a economia almejada.

De fato, nada impedia que o condomínio contratasse com outra empresa que fornecesse o mesmo serviço no mercado. Parece-nos, porém, e com todo o respeito à orientação firmada no caso concreto, que nem isso, nem a outra premissa suscitada no acórdão servem para afastar o direito do contratante à indenização pelo interesse positivo.

Isso porque o interesse positivo visa resguardar o estado ad quem em que o contratante lesado estaria não fosse o descumprimento da avença. Não se trata, portanto, necessariamente de "lucro", no sentido estrito da palavra.

Além disso, não se pode olvidar a causa econômica que é inerente aos contratos em geral. No caso narrado, verifica-se que ela corresponde à "economia" almejada com a substituição da portaria física pela virtual, que, ao menos durante determinado período, foi inviabilizada por conta do descumprimento contratual da ré. Com efeito, é justamente essa economia o dano positivo a ser tutelado e ressarcido.

O fato de haver outra empresa que pudesse substituir a Ré serve para estabelecer um parâmetro para definir a extensão do dano positivo, limitando-o a um período de tempo razoável, até que o condomínio pudesse finalizar a nova contratação, considerando-se as particularidades da contratação feita "em substituição" ${ }^{107}$. Afinal, tal dano não pode perdurar indefinidamente para o futuro, devendo o contratante observar o dever de mitigar o seu prejuízo.

A orientação tradicional também foi encontrada no TJDFT, no qual se decidiu que "[a]s perdas e danos, quando se trata de hipótese resolutiva, só podem compreender o prejuízo que o contratante experimentou por ter celebrado o contrato, ou seja, o prejuízo calcado no denominado interesse negativo". ${ }^{108}$

\footnotetext{
${ }^{107}$ Fazemos uso, uma vez mais, da terminologia adotada por Paulo Mota Pinto, ob. cit., vol. II., p. 1657

${ }^{108}$ E prossegue: "Não se pode, com efeito, conceber lucros cessantes advindos da privação do imóvel quando só se pode cogitar de tal privação se o promitente comprador opta por exigir o cumprimento da obrigação. Significa dizer que os Apelados optaram pela resolução e por conta disso o imóvel jamais integrou o seu patrimônio, de maneira que não têm direito aos rendimentos correspondentes à sua fruição.” (TJDFT, Ap. Civ. 0004338-23.2015.8.07.0001, 4ª Turma Cível, Rel. Des. James Eduardo Oliveira, j. 05.04.2017)
} 
Em sentido contrário, encontramos o paradigmático precedente do TJRS da lavra do então desembargador Ruy Rosado, talvez um dos mais antigos estudados no curso desse trabalho, cujo desfecho foi a condenação do vendedor inadimplente ao pagamento de indenização equivalente à diferença de preço na compra em substituição. ${ }^{109}$

A ação tinha por objeto pedido indenizatório por parte de um estaleiro por danos suportados em razão do inadimplemento de contrato para construção de um barco encomendado pelo autor da demanda. ${ }^{110}$

O caso é interessante, pois, a despeito do descumprimento por parte do estaleiro construtor, o autor não postulou a resolução contratual, mas, sim, o cumprimento do contrato e, subsidiariamente, não sendo o barco entregue, a condenação do réu a lhe indenizar pelo valor equivalente ao de uma embarcação nova, podendo o estaleiro reter o preço já pago, que, ainda que atualizado, seria insuficiente para alcançar o valor atualizado do bem.

A rigor, portanto, a pretensão autoral à indenização pelo interesse positivo - in casu, consistente na diferença entre o preço pago e o valor de um barco novo - não encontra óbice em nenhuma corrente doutrinária, posto que o autor requereu efetivamente o cumprimento do contrato, enquanto o motivo da controvérsia objeto desse estudo advém do pedido resolução do mesmo. Ou seja, era indiscutível o seu interesse no cumprimento e, consequentemente, o direito a ser reparado pelos respectivos danos.

Apesar disso, o juiz sentenciante, embora tenha reconhecido a impossibilidade do cumprimento da obrigação principal, condenou o réu apenas a restituir ao autor os valores pagos (interesse negativo), ensejando apelo, que foi provido pelo TJRS para condená-lo a "colocar o credor na situação em que estaria hoje se cumprido fosse o contrato" e, portanto, a pagar o equivalente ao valor atual do barco.

$\mathrm{Na}$ mesma linha, encontramos dois julgados do TJRJ, os quais, ao resolverem litígio entre construtora e o comprador de imóvel à luz do interesse positivo, consignaram, respectivamente que: "Não admitir a indenização por

\footnotetext{
${ }^{109}$ Trata-se, como visto no capítulo 1, de expressão usada por Paulo Mota Pinto, vol. II., ob. cit., p. 1657

${ }^{110}$ TRJS, AC nº 590081345, 5 CC, Rel Des Ruy Rosado de Aguiar Júnior, j. 21.12.1990
} 
lucros cessantes, neste caso, seria beneficiar o vendedor com seu inadimplemento, pois este acabaria por incorporar para si o lucro que decorreu da valorização do imóvel e que iria para o comprador caso o contrato fosse cumprido" ${ }^{111}$, bem como que "se a obrigação é um processo que busca a satisfação do interesse do credor mediante o seu adimplemento, o regime aplicável à inexecução dessa mesma obrigação deve buscar, de todas as formas, contornar o inadimplemento e tutelar esse interesse" ${ }^{\prime 12}$.

Ou seja, a Corte Fluminense admitiu a indenização por lucros cessantes lastreados no interesse positivo não obstante tenha a parte optado por resolver o contrato.

Com efeito, a despeito dos precedentes do e. STJ serem favoráveis à indenização pelo interesse positivo no caso de resolução contratual, nas instâncias ordinárias o tema ainda é bastante controvertido e pouco debatido.

Todos os julgados que afastaram a cumulatividade têm em comum, notadamente, a inobservância da teoria das diferenças e a possibilidade de o próprio magistrado delimitar a extensão do dano positivo, evitando eventual desequilíbrio da indenização à luz das particularidades de cada caso concreto.

Verificamos, ainda, que mesmo questões já uniformizadas perante o STJ, como é o caso das disputas imobiliárias, receberam tratamento diferenciado pelas Cortes ordinárias quando examinadas sob o prisma do interesse positivo.

Aqueles que adentraram mais a fundo na lógica por detrás da cumulatividade objeto desse trabalho, como é o caso dos precedentes do TJRJ, por sua vez, lograram transpor os aparentes óbices lançados pela doutrina tradicional.

\footnotetext{
${ }^{111}$ Ap. Civ. 0043141-91.2010.8.19.0203, 23 ${ }^{\mathrm{a}}$ CC, Rel. Des. Antonio Carlos dos Santos Bitencourt, j. 16.08 .2017

${ }^{112}$ Ap. Civ. 00169961420098190209, 16 a CC, Rel. Des. Lindolpho Morais Marinho, j. 24.05.2016
} 


\section{A POSIÇÃO ADOTADA NESSE TRABALHO}

Filiamo-nos à corrente favorável à possibilidade de cumulação do interesse positivo com a resolução contratual porquanto mais consentânea com o ordenamento jurídico brasileiro.

Além disso, parece-me que tal perspectiva melhor se alinha com a causa econômica do contrato e, sob um prisma meta jurídico, produz efeitos mais favoráveis à sociedade e à economia, trazendo mais segurança àqueles que acreditam no cumprimento do contrato (pacta sunt servanda); ao passo que a corrente tradicional, em última análise, ao desobrigar a parte infratora de arcar com o frustrado acréscimo patrimonial, acaba deixando de coibir adequadamente o inadimplemento, notadamente se considerarmos que, em termos práticos, dificilmente um empresário sensato, ao analisar os riscos envolvidos, optaria por prosseguir cumprindo com as prestações que lhe cabe em um contrato inadimplido.

Realmente, não faz sentido obrigar o credor a se manter cumprindo com as suas prestações e vinculado a um contrato que está sendo descumprido pela outra parte para que possa fazer jus à indenização pelo que auferiria com o contrato. Trata-se de racional contraproducente e contra desenvolvimentista.

Com o devido respeito à tese contrária, apesar dos argumentos por ela trazidos serem bastante convincentes, um exame mais aprofundado da lei brasileira, notadamente quanto aos efeitos da resolução contratual, revela não existir qualquer incompatibilidade lógica ou mesmo legal entre o texto da lei e o interesse em perseguir o dano positivo. Tampouco o propalado enriquecimento sem causa serve de entrave para obstar, prima facie, a cumulatividade, já que existem mecanismos que permitem ao magistrado evitá-lo, definindo os parâmetros da indenização à luz das particularidades de cada caso concreto (teoria das diferenças).

Com efeito, a interpretação que admite a cumulatividade parece ser a mais acertada, prevalecendo sobre a corrente tradicional em qualquer ângulo que analisemos os dispositivos legais aplicáveis (literal, teleológico, sistemático ou histórico). 
Historicamente, o interesse positivo é o que mais se aproxima à responsabilidade contratual, sendo reputado por muitos até mesmo incompatível com a culpa in contrahendo. Desse modo, deve-se sempre privilegiá-lo face o interesse negativo. ${ }^{113}$

A análise literal e sistemática dos arts. 475 e 402 do CC, por seu turno, revela que o legislador não fez nenhuma restrição à admissão do interesse positivo em caso de resolução contratual culposa, diferentemente de outros dispositivos (como os arts. 182 e 443 do CC, por exemplo), razão pela qual não cabe ao intérprete restringir, sob pena de malferir o princípio da reparação integral do dano. ${ }^{114}$

Por fim, sob uma perspectiva teleológica, a interpretação que limita o interesse do credor ao efeito restitutório e liberatório da resolução, ou seja, à reposição ao status quo ante, não se coaduna com a finalidade do instituto resolutório, que é resguardar os interesses do credor (e não restringir os seu direito à indenização) e, tampouco, encontra guarida junto ao art. 182 do CC o qual, como visto, dispõem sobre contratos inválidos, situação diversa da examinada.

Consoante teoria da causa econômica do contrato ${ }^{115}$, é certo dizer que as partes contratantes visam um determinado acréscimo patrimonial. Deve ser a satisfação deste, portanto, o fim natural da avença. Se, por culpa de um dos contratantes, o contrato teve de ser encerrado prematuramente, de forma anômala e sem que tal objetivo fosse atingido, cabe ao contratante culposo indenizar o outro pelo acréscimo patrimonial perdido. É preciso preservar o interesse do contratante adimplente.

$\mathrm{O}$ credor, ao resolver o contrato, almeja unicamente estancar a inadimplência e se liberar, apenas e tão somente, dos vínculos contratuais, inclusive para que possa, por exemplo, buscar novos contratos em substituição ao rescindido. Tal ato não pode ser interpretado como uma renúncia implícita ao seu direito de ser amplamente indenizado pelo ato culposo, inclusive, pelo acréscimo patrimonial indevidamente frustrado.

${ }^{113}$ Ruy Rosado, Extinção ..., ob. cit., p. 268

${ }^{114}$ Scartezzini, Ob. Cit, p. 11.

${ }^{115}$ Como bem observado por Theodoro Júnior, o contrato é um instituto de origem "econômica e tem fins econômicos a realizar, que não podem ser ignorados pela lei e muito menos pelo aplicador da lei", de modo que "contrato sem função econômica simplesmente não é contrato". (In $O$ contrato e sua função social. 2. ed. Rio de Janeiro: Forense, 2004, p. 100-101) 
Além da lógica muito bem desenvolvida pela doutrina, esmiuçada no capítulo 2.2.2, convém acrescentar que o entendimento contrário viola a literalidade do art. 114 do CC, cuja redação é clara ao estabelecer "[o]s negócios jurídicos benéficos e a renúncia interpretam-se estritamente". Desse modo, salvo expressa exceção legal, a renúncia de direitos não se presume.

O objetivo fim almejado com o contrato (acréscimo patrimonial) não pode ser olvidado na equação indenizatória, sob pena de se tornar sem efeito a contratação e fazer letra morta do princípio básico da obrigatoriedade dos contratos (pacta sunt servanda). Consequentemente, não se pode deixar de reparar o status ad quem que a parte inocente deixou de auferir em razão da conduta lesiva da parte contrária.

Afinal, de que vale o contrato se, ao final do dia, justamente a parte que atuou ilicitamente, dando ensejo à resolução do ajuste, é premiada com a isenção de cumprir com aquilo que se obrigara originalmente?!

A indenização pelo interesse positivo em caso de resolução também não gera desequilíbrio contratual, pois não é a contraprestação da parte infratora, em si, o objeto da indenização, mas, sim, o resultado final esperado do contrato. Assim, não é preciso manter as partes vinculadas para que o credor possa ser indenizado por aquilo que auferiria com contrato.

Tampouco se justifica a manutenção do vínculo com base na vedação ao enriquecimento sem causa do credor, que receberia acréscimo patrimonial sem entregar a respectiva contraprestação. Afinal, basta aplicar a teoria das diferenças, abatendo-se do acréscimo patrimonial as prestações restituídas ou retidas pelo credor, considerando-se, sempre as particularidades de cada caso concreto.

$\mathrm{O}$ que não faz nenhum sentido, com o devido respeito àqueles que se posicionam em sentido contrário, é se obrigar o credor a continuar a arcar com a suas obrigações contratuais mesmo ciente de que o devedor já não está cumprindo com as dele para que possa obter a justa indenização.

De igual forma, não nos parece razoável exigir do credor que postule, primeiramente, o cumprimento de um contrato que já se sabe, de antemão, não será satisfeito, para, então, somente após ser judicialmente confirmada a persistência do incumprimento, conferir a ele o direito de converter a obrigação 
contratual em indenização pelo interesse positivo. Tal procedimento, excessivamente formal, apenas burocratiza e encarece as relações contratuais. Se já se sabe que, ao final, o contrato não será cumprido, porque se exigir uma etapa intermediária para, somente então, converter a obrigação descumprida em perdas e danos?! A transformação do contrato em liquidação de danos, sugerida pela doutrina de vanguarda, é muito mais econômica e eficiente para todos, inclusive à Justiça.

Por outro lado, com razão Renata Steiner $^{116}$ afirma que a relação de liquidação iniciada pela resolução contratual possui três eficácias distintas liberatória, restitutória e indenizatória - e que todas elas devem ser analisadas para que a composição do dano pelo descumprimento seja plenamente satisfeita.

A restituição daquilo que prestou (eficácia restitutória) ou mesmo a interrupção daquilo que deveria prestar (eficácia liberatória), não pode substituir aquilo que o contratante pretendia obter com o contrato, reparável mediante indenização (eficácia indenizatória), sob pena de se fazer letra morta do princípio da reparação integral contido nos art. 944 e 402 do CC.

Considerando que (i) o contrato visa ao adimplemento; (ii) foi o devedor quem deu causa à resolução; (iii) o inadimplemento, per si, já deixa o credor em uma situação de desvantagem perante o devedor, já que o objetivo dele com o contrato não era receber de volta a sua prestação, mas, sim, obter o acréscimo patrimonial que se obteria com o devido cumprimento contrato; (iv) não parece razoável limitar o direito do credor à restituição do que prestou e indenização pelo que desembolsou para celebrar o contrato. Pelo contrário, tal conjectura deixa a parte inadimplente em uma situação muito mais confortável do que a da parte adimplente, invertendo completamente a lógica do justo deslinde da questão.

Se o credor lesado, por conta do seu esforço e mérito próprio, eventualmente logrou compensar os prejuízos do contrato descumprido mediante celebração de novo negócio com um terceiro, tal circunstância não isenta a parte inadimplente da sua responsabilidade. A obrigação de indenizar pelo interesse positivo persiste. A diferença é que, nessa última hipótese, poder-se-ia, talvez,

116 Ob. cit., p. 295. 
discutir, no curso da fase de liquidação ${ }^{117}$, a quantificação (ou seja, o valor, a extensão) do dano, já que mitigado pelo comportamento diligente do contratante lesado. ${ }^{118}$

Assim, não obstante as honrosas vozes em sentido contrário, não me parece razoável invocar a (eventual) possibilidade de sucesso do credor em contratar com terceiros após se liberar do contrato como argumento para, antecipadamente, retirar dele o direito de ser reparado pelo lucro frustrado pelo devedor.

A bem da verdade, tal linha de raciocínio chega a ser até mesmo ilógica já que, além de transferir os louros do credor diligente para o devedor (que fica isento de responsabilidade pela proatividade da parte lesada), põe fim ao direito indenizatório do credor com base em um evento futuro e incerto, antes mesmo dele ser verificado.

Por tudo isso é que entendo plenamente defensável a tese de que, assim como no direito germânico, italiano e francês, a legislação brasileira também não obsta a cumulatividade, cuja aplicação, na verdade, encontra resistência em razão, unicamente, da ultrapassada interpretação extensiva e ilimitada dos efeitos da resolução contratual. Ora, se mesmo em Portugal, onde a literalidade do direito positivo dava guarida à tese tradicional, a mesma foi superada, com maior razão deve sê-lo no direito brasileiro, no qual não existe qualquer norma que vincule os efeitos da resolução contratual à morte do contrato. ${ }^{119}$

A fragilidade da doutrina tradicional, portanto, é que ela se encontra exclusivamente conectada à retroatividade plena da resolução contratual, deixando de lado uma série de outras questões de índole jurídica, prática e até mesmo meta jurídica (econômica e social) que acabam se sobrepondo àquela perspectiva mais restrita.

\footnotetext{
117 Ruy Rosado, Extinção..., p. 266.

${ }^{118}$ Sobre este ponto, Renata Steiner pondera que "Se o lesado manteve consigo o bem (seja porque liberou-se da prestação, seja porque essa lhe foi restituída), o seu valor deve ser considerado no cálculo do prejuízo sofrido com a falta de cumprimento. $O$ que não parece adequado, contudo, $e$ reafirmando a distinção afirmada entre restituição e indenização, é pressupor sua identificação. Nem sempre a devolução do bem manterá ao credor a possibilidade de obtenção integral do lucro contratual que se esperava com a venda." (Ob. cit., p. 296; g.n.)

${ }^{119}$ Scartezzini. ob. cit., p. 11.
} 
Por isso, faço coro à doutrina de Paulo Mota Pinto, quando afirma "que a posição que veda ao credor que resolve o contrato exigir simultaneamente uma indenização por não cumprimento se encontra em claro recuo" ${ }^{120}$, inclusive à luz do ordenamento jurídico brasileiro.

${ }^{120}$ Paulo Mota Pinto, ob. cit., p. 1638. 


\section{CONCLUSÃO}

Como visto o interesse contratual negativo e o interesse contratual positivo vêm sendo profundamente estudados e debatidos na Europa desde o século XIX, quando foram idealizados por Jhering para defender a responsabilidade précontratual e diferenciá-la da tutela contratual.

De lá para cá os institutos em questão sofreram influência de novas correntes doutrinárias, ganhando maior expressão e abrangência, notadamente o interesse negativo, que passou a albergar a tutela da confiança e a ser admitido também no âmbito da responsabilidade contratual.

Mantida a essência conceitual original, chegou-se, atualmente, à ampla definição de interesse negativo como sendo a situação hipotética em que a parte se encontraria se não houvesse confiado na eficácia do contrato. O restabelecimento dessa situação hipotética é feito mediante restituição ao status quo ante. A sua indenização, compreende, assim, as despesas incorridas com o contrato em si e/ou com a sua negociação, bem como o lucro que o contraente deixou de auferir com outro contrato, deixado de lado por conta do pacto e/ou negociação frustrado.

Já o interesse positivo corresponde à situação hipotética patrimonial na qual o lesado estaria se o contrato houvesse sido adequadamente cumprido, de modo que se busca recolocar o lesado em um estado ad quem, mediante a adição de um elemento que deveria ter ocorrido e não ocorreu (cumprimento do contrato). Indeniza-se, portanto, o acréscimo patrimonial obstado pela parte inadimplente.

A par dessa conceituação, bem como dos efeitos clássicos da resolução contratual estabelecidos pela legislação positiva de alguns países europeus, surgiu a celeuma em torno do cabimento da indenização pelo interesse positivo nos casos em que o contraente tenha optado por resolver o contrato inadimplido.

Por longa data entendeu-se que o interesse do credor em ser indenizado por aquilo que auferiria com o contrato seria incompatível com a resolução do mesmo, cujo o efeito, segundo as normas dos países europeus então em vigor, era a completa extinção, retroativa, da avença. 
Com a evolução legislativa, tal posição tradicional acabou sendo superada em países como Alemanha, França e Itália. Mais recentemente, foi suplantada pelo Supremo Tribunal de Justiça Português que, à luz da moderna doutrina de Paulo Mota Pinto, relativizou a interpretação do direito positivo em vigor naquele país e restringiu os efeitos da resolução contratual, admitindo, assim, a sua cumulatividade com o interesse contratual positivo.

Trazendo o debate para o direito brasileiro, verificou-se que, a despeito da legislação local não atribuir à resolução contratual efeito extintivo ilimitado, parte respeitável da doutrina importou integralmente a orientação tradicional lusitana, passando, então, a sustentar a incompatibilidade lógica acima pontuada. Tal linha ganhou adeptos também por conta da vagueza com que o art. 402 do CC define as perdas e danos.

Embora convincente à primeira vista, demonstrou-se que a tese tradicional não sobrevive à análise aprofundada dos institutos em questão à luz do ordenamento civil pátrio.

Considerando-se o princípio da reparação integral, a finalidade precípua do instituto da resolução contratual, bem como a interpretação conjunta dos arts. 475, 402, 944 e 114 do CC, sistematizada com outros dispositivos legais em vigor, como é o caso dos arts. 75 e 76 da CISG e dos art. 182 e 443 do CC; não resta dúvida de que a incompatibilidade antes sustentada no direito europeu (e hoje já superada) não encontra guarida em território nacional.

Além do Código Civil não prever a morte do contrato pela resolução, como faz o direito lusitano, tal leitura descaracteriza a resolução, transformando quase que em veneno, o que deveria ser um remédio para proteger o credor, notadamente se considerarmos a dificuldade usualmente encontrada para se comprovar os lucros cessantes no âmbito do dano negativo.

Verificou-se, ainda, que nada há de ilógico em se indenizar o interesse positivo do credor que rescinde o contrato. Pelo contrário, incoerente seria admitir que a resolução põe fim, de maneira fictícia, a todo e qualquer dever e obrigação das partes, inclusive ao de integral reparação, beneficiando o devedor que deu causa à extinção anômala da avença em detrimento do credor; justamente aquele que promoveu a resolução para encerrar a situação de inadimplemento. 
Também não há de ser falar em prêmio ao credor e em quebra do sinalagma, pois a cumulatividade entre os institutos em estudo, se corretamente aplicada, não o coloca em situação melhor do que estaria se o contrato fosse cumprido. Afinal, além das prestações contratuais não se confundirem com a indenização que se torna devida, basta que o aplicador do direito abata do quantum indenizatório o valor das prestações retidas e/ou restituídas ao credor por conta da resolução.

Por fim, a cumulatividade parece ser mais consentânea à função econômica do contrato e contribuir para criar um ambiente de maior confiança no cumprimento do contrato, desfecho normal esperado pelos contraentes, servindo, por isso, de estímulo ao desenvolvimento comercial com risco (e, consequentemente, custo) mais baixo.

Não por outro motivo, embora as Cortes ordinárias ainda demonstrem certa resistência à tese ora defendida nos poucos casos em que se debruçaram sobre a matéria, a jurisprudência do STJ, conquanto igualmente escassa, consolidou-se favoravelmente ao cabimento da indenização pelo interesse positivo mesmo que o credor tenha optado por resolver o contrato. 


\section{QUADRO SINÓPTICO}

\section{Pontos de consenso}

- Os lucros cessantes e danos emergentes estão presentes tanto no interesse positivo quanto no interesse negativo.

- Interesse positivo e interesse negativo não se confundem, respectivamente, com lucros cessantes e danos emergentes.

\section{Principais pontos debatidos}

\section{Corrente contrária}

- Aplica-se por analogia o art. 182 do CC que impõe a restituição das partes ao status quo ante em caso de resolução, situação incompatível com o acréscimo patrimonial que seria auferido com o contrato.

- Os efeitos da resolução contratual retroagem plenamente, extinguindo o contrato desde a sua origem, liberando os contraentes de eventuais prestações pendentes (efeito liberatório) e garantindo a eles o direito de reaver as parcelas pagas (efeito restitutório), o que significa que ambos os contraentes devem retornar ao estado em que se encontravam como se o contrato não tivesse existido.

- Consequentemente, nesse cenário, admitir que o credor, além de receber de volta a parte da sua prestação que fora entregue ao devedor, cumulativamente, ainda receba deste o acréscimo patrimonial contratual que auferiria com o contrato, implica em colocá-lo em situação melhor do que estaria se o contrato tivesse sido adequadamente cumprido, caracterizando o seu enriquecimento injustificado e desequilíbrio contratual (quebra de sinalagma).

\section{Corrente favorável}

- É descabida a aplicação analógica do art. 182 do $\mathrm{CC}$, pois voltado aos contratos inválidos (nulos ou anulados), situação muito diferente dos contratos que são válidos, mas descumpridos,

- O efeito extintivo da resolução se opera apenas quanto às prestações contratuais principais, sem prejuízo ao direito indenizatório, sob pena de se subverter a finalidade da resolução, que é um remédio voltado a proteger o credor, não o devedor. Admitir que o contrato e todos os deveres e obrigações a ele inerentes jamais existiram implica em admitir que o próprio descumprimento contratual e a própria resolução também não ocorreram, o que é absolutamente ilógico.

- Os efeitos liberatórios e restitutórios não se confundem com o direito à indenização e são plenamente conciliáveis, não havendo que se falar em enriquecimento sem causa, contanto que, no momento da liquidação do dano, seja observada a teoria das diferenças, compensando-se as prestações retidas e/ou restituídas com o benefício contratual que seria auferido pela parte (interesse positivo). 
- Ao resolver o contrato a parte desiste do mesmo, razão pela qual é incoerente que venha postular indenização pelo seu cumprimento.

- Os efeitos da resolução somados ao interesse positivo configurariam um verdadeiro benefício à parte lesada, ultrapassando os limites da reparação integral estabelecidos pelo art. 944 do CC.
- Ilógico é usar em desfavor do credor, limitando o seu direito, um remédio preventivo (a resolução) que é feito para resguardá-lo. Ao resolver o contrato, o credor almeja apenas liberar-se das prestações contratuais, desfazendo-se do vínculo contratual, até mesmo, para evitar o agravamento da sua situação. Não há renúncia e ela não pode ser tacitamente considerada.

- Além dos efeitos da resolução não possuírem a extensão defendida pela corrente contrária, pelos motivos acima expostos, as amplas disposições dos arts. 402 e 475 do CC, cujas redações não limitam o dano indenizável como fazem outros artigos da mesma lei, levam a crer que neles estão abrangidos tanto $\mathrm{o}$ interesse positivo, quanto o negativo, sem espaço à interpretação restritiva proposta pela corrente tradicional. Por fim a cumulatividade é prevista na CISG, que possui força de lei no Brasil. 


\section{REFERÊNCIAS BIBLIOGRÁFICAS}

ANTUNES VARELA, João de Matos. Das Obrigações em Geral, Volume II. 7. ${ }^{\text {a }}$ Edição, Coimbra: Ed. Almedina, 1997

AGUIAR JUNIOR, Ruy Rosado de. Extinção dos contratos por incumprimento do devedor. Rio de Janeiro: AIDE Editora, 2003.

Comentários ao Novo Código Civil, volume vi, tomo II: da extinção do contrato. Coord. Sálvio de Figueiredo Teixeira. Rio de Janeiro: Forense, 2011.

CORDEIRO. António Manuel da Rocha e Menezes, Tratado de direito civil português, $2^{\circ}$ Vol: Direito das obrigações, Tomo IV. Coimbra: Almedina, 2010.

ASSIS, Araken de. Resolução do contrato por inadimplemento. 5. ed. São Paulo: Ed. RT, 2013.

FARIA. Jorge Leite Areias Ribeiro de. Direito das obrigações, vol.2. Coimbra: Almedina, 1990.

FARIAS, Cristiano Chaves de; ROSENVALD, Nelson. Curso de direito civil: contratos - teoria geral e contratos em espécie. 5 ed. rev. e atual. Salvador: Ed. Atlas, 2015.

GOMES, Orlando. Contratos. 25. Ed. Atual. Humberto Theodoro Junior, Rio de Janeiro: Forense, 2002.

GUEDES, Gisela Sampaio da Cruz. Lucros cessantes: do bom senso ao postulado normativo da razoabilidade, São Paulo: RT, 2011.

GUIMARÃES, Paulo Jorge Scartezzini. Responsabilidade civil e interesse contratual positivo e negativo (em caso de descumprimento contratual). In: Revista de Direito Privado. Vol. 63/2015, pp. 33-58. Jun/Set 2015. São Paulo, RT, acesso pela RTOnline.

MARTINS-COSTA, Judith. Responsabilidade civil contratual. Lucros cessantes. Resolução. Interesse positivo e interesse negativo. Distinção entre lucros cessantes e lucros hipotéticos. Dever de mitigar o próprio dano. Dano moral e pessoa jurídica, in: Renan Lotufo, Giovanni Ettore Nanni e Fernando Rodrigues Martins (orgs.), Temas relevantes de direito civil contemporâneo, São Paulo: Atlas, 2012.

Um aspecto da obrigação de indenizar: notas para uma sistematização dos deveres pré-negociais de proteção no direito civil brasileiro. In: Doutrinas Essenciais do Direito Civil. Vol. 4, pp. 693-746. Out/2010. São Paulo, RT, acesso pela RTOnline.

MOTA PINTO, Paulo. Interesse contratual negativo e interesse contratual positivo. vol. I e vol. II. Coimbra: Ed. Coimbra, 2008. 
PONTES DE MIRANDA, Francisco Cavalcanti. Tratado de Direito Privado Parte Especial: Direito das obrigações: negócios jurídicos bilaterais e negócios jurídicos plurilaterais. Pressupostos. Vícios de direito (...). 2. Ed. Rio de Janeiro: Borsoi, 1962. t. XXXVIII.

SZTAJNBOK, Felipe. A indenização pelo interesse positivo como forma de tutela do interesse do credor nas hipóteses de inadimplemento culposo da obrigação. Civilistica.com. Rio de Janeiro, a. 3, n. 2, jul.-dez./2014. Disponível em: $<$ http://civilistica.com/a-indenizacao-pelo-interesse-positivo-como-forma-detutela-do-interesse-do-credor-nas-hipoteses-de-inadimplemento-culposo-daobrigacao/>. Acesso em: 2019-01.02.

STEINER, Renata Carlos. Interesse positivo e Interesse negativo: a reparação de danos no direito privado brasileiro. 2016. Tese (Doutorado em Direito Civil) Faculdade de Direito, Universidade de São Paulo, São Paulo, 2016. doi:10.11606/T.2.2016.tde-20082016-121314. Acesso em: 2019-01-02.

THEODORO JÚNIOR, Humberto. O contrato e sua função social. 2. ed. Rio de Janeiro: Forense, 2004. 